\title{
Negative emissions and international climate goals-learning from and about mitigation scenarios
}

\author{
Jérôme Hilaire ${ }^{1,2} \cdot$ Jan C. Minx ${ }^{1,3} \cdot$ Max W. Callaghan ${ }^{1} \cdot$ Jae Edmonds $^{4}$. \\ Gunnar Luderer $^{2} \cdot$ Gregory F. Nemet $^{5} \cdot$ Joeri Rogelj $^{6,7,8} \cdot$ Maria del Mar Zamora $^{1}$
}

Received: 27 December 2017 / Accepted: 8 August 2019/Published online: 17 October 2019

(C) The Author(s) 2019

\begin{abstract}
For aiming to keep global warming well-below $2{ }^{\circ} \mathrm{C}$ and pursue efforts to limit it to $1.5^{\circ} \mathrm{C}$, as set out in the Paris Agreement, a full-fledged assessment of negative emission technologies (NETs) that remove carbon dioxide from the atmosphere is crucial to inform science-based policy making. With the Paris Agreement in mind, we re-analyse available scenario evidence to understand the roles of NETs in $1.5^{\circ} \mathrm{C}$ and $2{ }^{\circ} \mathrm{C}$ scenarios and, for the first time, link this to a systematic review of findings in the underlying literature. In line with previous research, we find that keeping warming below $1.5^{\circ} \mathrm{C}$ requires a rapid large-scale deployment of NETs, while for $2{ }^{\circ} \mathrm{C}$, we can still limit NET deployment substantially by ratcheting up near-term mitigation ambition. Most recent evidence stresses the importance of future socio-economic conditions in determining the flexibility of NET deployment and suggests opportunities for hedging technology risks by adopting portfolios of NETs. Importantly, our thematic review highlights that there is a much richer set of findings on NETs than commonly reflected upon both in scientific assessments and available reviews. In particular, beyond the common findings on NETs underpinned by dozens of studies around early scale-up, the changing shape of net emission pathways or greater flexibility in the timing of climate policies, there is a suite of "niche and emerging findings", e.g. around innovation needs and rapid technological change, termination of NETs at the end of the twenty-first century or the impacts of climate change on the effectiveness of NETs that have not been widely appreciated. Future research needs to explore the role of climate damages on NET uptake, better understand the geophysical constraints of NET deployment (e.g. water, geological storage, climate feedbacks), and provide a more systematic assessment of NET portfolios in the context of sustainable development goals.
\end{abstract}

Keywords Negative emission - Carbon dioxide removal - Systematic evidence synthesis · Integrated assessment model $\cdot 1.5^{\circ} \mathrm{C} \cdot 2{ }^{\circ} \mathrm{C}$

Electronic supplementary material The online version of this article (https://doi.org/10.1007/s10584-01902516-4) contains supplementary material, which is available to authorized users.

Jérôme Hilaire

hilaire@pik-potsdam.de

Extended author information available on the last page of the article 


\section{Introduction}

Fast dwindling carbon budgets are stimulating a lively debate on the role of negative emission technologies $\left(\mathrm{NETs}^{1}\right)$ for keeping warming below $1.5^{\circ} \mathrm{C}$ and $2{ }^{\circ} \mathrm{C}$, as illustrated by a growing number of scientific and policy discussions on the subject (Fuss et al. 2014; Geden 2015; Lomax et al. 2015; Gasser et al. 2015; Anderson 2015; Lewis 2015; Williamson 2016; Anderson and Peters 2016; Lackner 2016; Field and Mach 2017; Parson 2017; Peters and Geden 2017; Geden and Löschel 2017; van Vuuren et al. 2017; Obersteiner et al. 2018; Scott and Geden 2018). At the heart of these discussions lays new evidence from long-term climate change mitigation scenarios generated with integrated assessment models (IAMs) as summarized in recent assessments by the Intergovernmental Panel on Climate Change (Bruckner et al. 2014; Clarke et al. 2014; IPCC 2014; Kunreuther et al. 2014; Smith et al. 2014; Stavins et al. 2014).

The Fifth Assessment Report (AR5) by IPCC Working Group 3 (WG3) provided a good overview of the role of NETs for stringent climate stabilization targets. It highlighted that many $2{ }^{\circ} \mathrm{C}$ scenarios entail large-scale deployment of NETs after 2050 to compensate for residual $\mathrm{CO}_{2}$ emissions from sectors that are difficult to decarbonize, such as industry and aviation. It warned that these scenarios are mostly associated with a temporary overshoot of the climate goal and that delays in climate action and limitations in the availability of NETs can render the $2{ }^{\circ} \mathrm{C}$ goal infeasible. It also emphasized the challenges (e.g. societal concerns), risks (e.g. technological availability, biodiversity, water, food prices, inter-generational impacts) and uncertainties (e.g. geological storage, large bioenergy production) surrounding these technologies (see also Electronic Supplementary Material (ESM) for a complete review of NET statements in AR5).

Yet, the analysis of NETs in WG3 AR5 remained inaccessible because findings were scattered in various sections and sub-sections of the report (i.e. in Chaps. 2, 6, 7, 11, 13).

The recent IPCC Special Report on Global Warming of $1.5^{\circ} \mathrm{C}$ (SR1.5) (IPCC 2018) filled this gap by drawing upon a set of recent reviews (Minx et al. 2018; Fuss et al. 2018; Nemet et al., 2018) that used formal methods of evidence synthesis. It further added a comprehensive analysis on the role of NETs in $1.5{ }^{\circ} \mathrm{C}$ scenarios based on newly emerging evidence. The report highlighted that all $1.5^{\circ} \mathrm{C}$ scenarios with limited or no overshoot require NETs on the order of $100-1000 \mathrm{GtCO}_{2}$ over the twenty-first century but that significant near-term emissions reductions (e.g. low energy demand, low material consumption, low GHG-intensive food consumption) can limit NET deployment to a few hundred $\mathrm{GtCO}_{2}$ without reliance on Bioenergy with Carbon Capture and Storage (BECCS). It also called attention to the lack of published pathways featuring NETs other than afforestation and reforestation (AR) and BECCS (see also Electronic Supplementary Material (ESM) for a complete review of NET statements in Fuss et al. 2018, IPCC 2018 and Rogelj et al. 2018b).

Despite all this progress in the understanding of NETs, the assessment practice on scenario evidence remains unsatisfactory. In particular, the imbalance in systematicity between the treatment of quantitative and qualitative findings is concerning. On the one hand, pathways are extracted from various studies, pulled together in a large database and analysed in a complete

\footnotetext{
${ }^{1}$ In this review, we consider NET as any human action that removes $\mathrm{CO}_{2}$ from the atmosphere. This definition includes: afforestation and reforestation (AR), bioenergy with carbon capture and storage (BECCS), biochar, direct air capture and carbon storage (DACCS), enhanced weathering (EW), ocean alkalinisation (OA), ocean fertilisation (OF), soil carbon sequestration. See ESM for more details.
} 
systematic fashion. On the other hand, the inclusion or exclusion of qualitative findings is left to the discretion of the expert review team. While analyses based on larger scenario ensembles are more robust and generate new synthetic insights, the lack of a systematic approach for qualitative evidence is problematic for at least three reasons. First, the absence of systematic methods overall in many circumstances leads to bias (Haddaway and Macura, 2018). Second, findings in reviews and scientific assessments cannot be traced back to all relevant studies. For instance, the sentence "CDR requirements are reduced under 'sustainability' related assumptions." (Rogelj et al. 2018b, p. 149) only cites Strefler et al. (2018) while studies by Bertram et al. (2018) and van Vuuren et al. (2018) are equally relevant. In a similar vain, evidence resulting from the analysis of large databases - those created specifically for reviews and assessments - can be disconnected from original findings. These problems reduce the transparency of synthetic works, a crucial element of any systematic approach. Finally, we argue and will show in this article that the lack of systematicity also runs the risk of omitting important niche and newly emerging results.

To address these shortcomings with a view on the upcoming Sixth Assessment Report (AR6), we present here the first thematic review (Boyatzis 1998; Guest et al. 2012) of the available scenario literature on NETs; provide a comprehensive, traceable and easily updatable synthetic table of all statements on NETs; and re-analyse the most important ones quantitatively. The main novelty of our approach is that it links a systematic assessment of individual findings to the literature base and evidence from scenario data. As in any systematic approach, we describe the procedures to search and select the literature, to extract evidence and to evaluate the quality of included studies in a comprehensive and transparent manner (Petticrew and McCartney 2011; Minx et al. 2017a). Such a method provides a crucial synthetic account to inform upcoming climate change assessments. In particular, we contribute to the systematic assessment literature by developing and employing a computer-assisted method to review 138 studies on the subject in a comprehensive and transparent manner, allowing us to synthesize many qualitative findings. We complement this analysis by connecting it to a summary of the available quantitative evidence. Our review includes the rapidly emerging literature on the $1.5^{\circ} \mathrm{C}$ limit (Luderer et al. 2013, 2018; Rogelj et al. 2015, 2018a, b; Manoussi et al. 2017; Marcucci et al. 2017; Mintenig et al. 2017; Bauer et al. 2018; Bertram et al. 2018; Holz et al. 2018; Kriegler et al. 2018a; Rickels et al. 2018; Strefler et al. 2018; Séférian et al. 2018; van Vuuren et al. 2018; Grubler et al. 2018) that include scenarios that emphasise the role of NETs even more than the $2{ }^{\circ} \mathrm{C}$ scenarios in AR5.

Importantly, our approach provides:

- a ready-to-use method for systematically reviewing the scenario literature;

- a comprehensive, traceable and easily updatable synthetic table that maps 1360 paragraphs from 138 studies related to NETs into 66 summary statements (see Excel spreadsheet in ESM);

- a focused assessment of key evidence on the distinct role of NETs for limiting climate change to $1.5{ }^{\circ} \mathrm{C}$ and $2{ }^{\circ} \mathrm{C}$, respectively (i.e. upscaling, maximum deployment, near-term mitigation trade-offs, role of socio-economic drivers, regional NET deployment);

- an improved understanding of how deployment dynamics change as multiple NETs get deployed in small portfolios.

In the next section, we review some key findings on NETs that are important to understand scenario results and are particularly useful for the discussions of the $1.5^{\circ} \mathrm{C}$ and $2{ }^{\circ} \mathrm{C}$ limits. We 
support this review with quantitative evidence on the dynamics of emission pathways, climate change mitigation costs, and regional $\mathrm{CO}_{2}$ sequestration whilst giving some special attention to small NET portfolios. Throughout the analysis, we discuss relevant key assumptions as appropriate. We close by providing a more comprehensive overview of the landscape of findings and discuss major open avenues for research.

\section{Main findings from the scenario literature}

The statements on NETs that we synthesized from the available literature and that are relevant to the focus of this review are organized in Table 1. We refer to them in the remainder of this article by using their unique identifier (e.g. O1, see column ID in Table 1). The methodology employed to find each statement is detailed in the ESM. It should be noted that in most mitigation scenarios, BECCS is the only explicit NET available. ${ }^{2}$ Unless a statement is specific to a particular NET, we therefore consider BECCS as a proxy for NETs in the following discussion and as a result interpret its deployment as total NET deployment. Towards the end of this section, we explicitly consider portfolios with multiple NETs.

The literature highlights the importance of NETs for meeting stringent climate policy targets $\mathrm{O} 1$. This importance is illustrated by the large amounts of carbon withdrawn from the atmosphere in most $1.5^{\circ} \mathrm{C}$ and $2{ }^{\circ} \mathrm{C}$ scenarios. In $85 \%$ of $2{ }^{\circ} \mathrm{C}$ scenarios (above 15 th percentile), more than $300 \mathrm{Gt} \mathrm{CO}_{2}$ are removed over the twenty-first century as long as no drastic GHG emission abatement, radical changes towards sustainable lifestyles, nor constraints on technological availability and climate policy timing are imposed (see Fig. 1a1 vs Fig. 1a2-a4). This estimate increases to nearly 500 in $1.5^{\circ} \mathrm{C}$ scenarios with similar assumptions (Fig. 1a5).

Differences in cumulative carbon removal reflect qualitative differences in $1.5^{\circ} \mathrm{C}$ and $2{ }^{\circ} \mathrm{C}$ scenarios. Global warming cannot be limited to $1.5^{\circ} \mathrm{C}$ without NETs because the overshoot of the small carbon budget associated with this goal ${ }^{3}$ - resulting from socio-economic inertiasmust be offset by negative emissions (Fig. 1a) (Luderer et al. 2013; Rogelj et al. 2015; Strefler et al. 2018; Rogelj et al. 2018a; Kriegler et al. 2018b). In other words, in the absence of largescale negative emissions, scenarios without draconian near-term $\mathrm{CO}_{2}$ emission reductions are infeasible $\mathrm{O} 11$ (Fig. 1a6, see Table 2 for illustration). Even in recent $1.5^{\circ} \mathrm{C}$ scenarios that explore goal achievement with minimum NETs, net negative emissions during the second half of the twenty-first century are required (Bertram et al. 2018; Holz et al. 2018; van Vuuren et al. 2018; Grubler et al. 2018) (Fig. 1a6). In contrast, a variety of $2{ }^{\circ} \mathrm{C}$ scenarios exist without any explicit NET deployment, although the near-term $\mathrm{CO}_{2}$ emission reductions envisaged in these scenarios are more severe than when NETs are deployed (Fig. 1a2) (Krey et al. 2014; Kriegler et al. 2014; Iyer et al. 2015; Eom et al. 2015). Moreover, the global economy is fully decarbonised by the second half of the twenty-first century in $1.5^{\circ} \mathrm{C}$ scenarios D2 with a sustained period of net negative emissions thereafter. The scale-up of NETs between 2030 and

\footnotetext{
${ }^{2}$ This is mostly the case for scenarios prior to AR5. New scenarios increasingly feature 2 or more NETs. In addition, the new scenario data reporting template from the Integrated Assessment Modelling Consortium now separates individual NET contributions (e.g. Carbon Sequestration|CCS|Biomass, Carbon Sequestration|Land Use|Afforestation, Carbon Sequestration|Land Use|Biochar, Carbon Sequestration|Direct Air Capture, Carbon Sequestration|Enhanced Weathering...).

${ }^{3}$ To date, no publicly available scenario considers the much larger carbon budget estimate from Millar et al. (2017).
} 


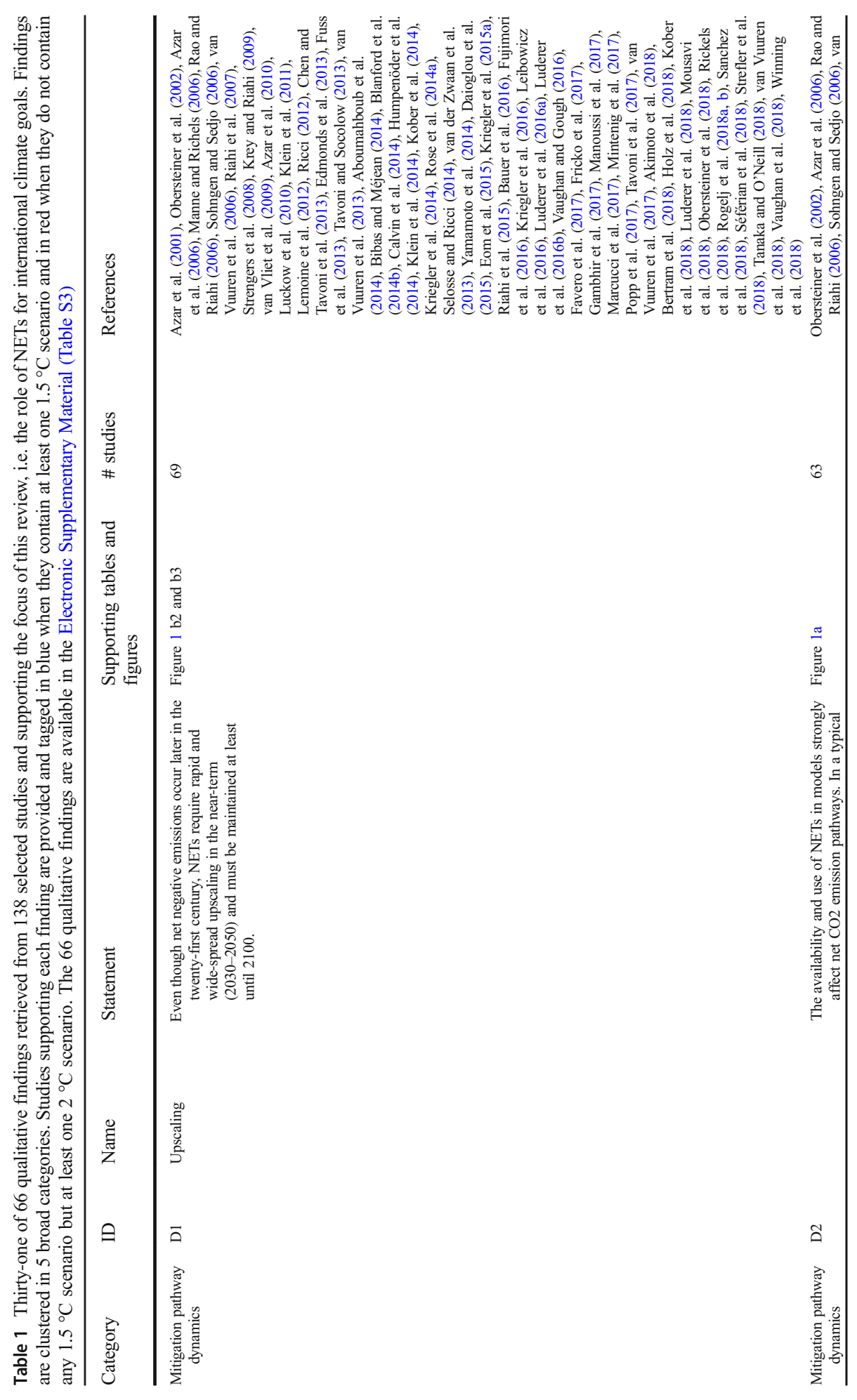




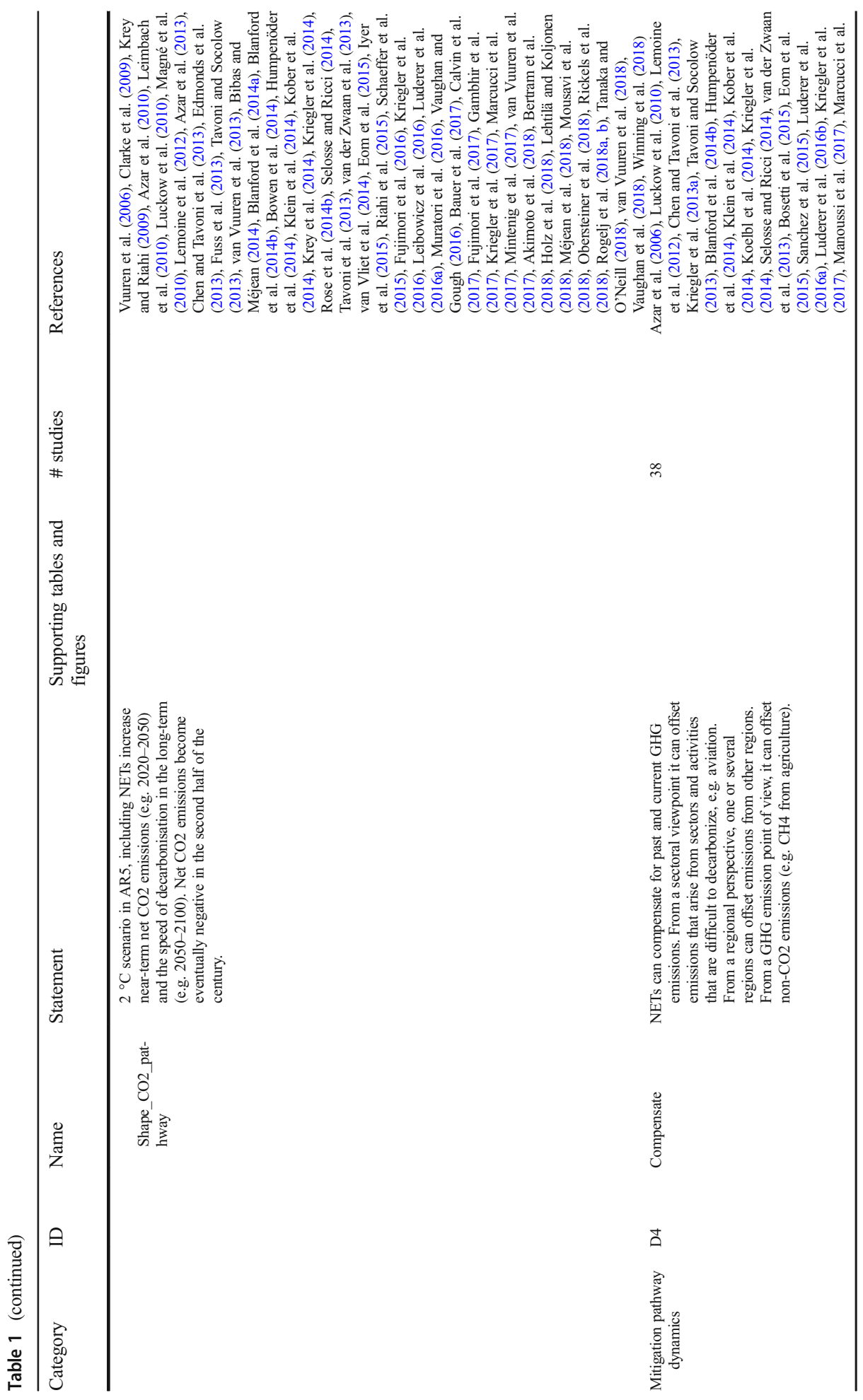




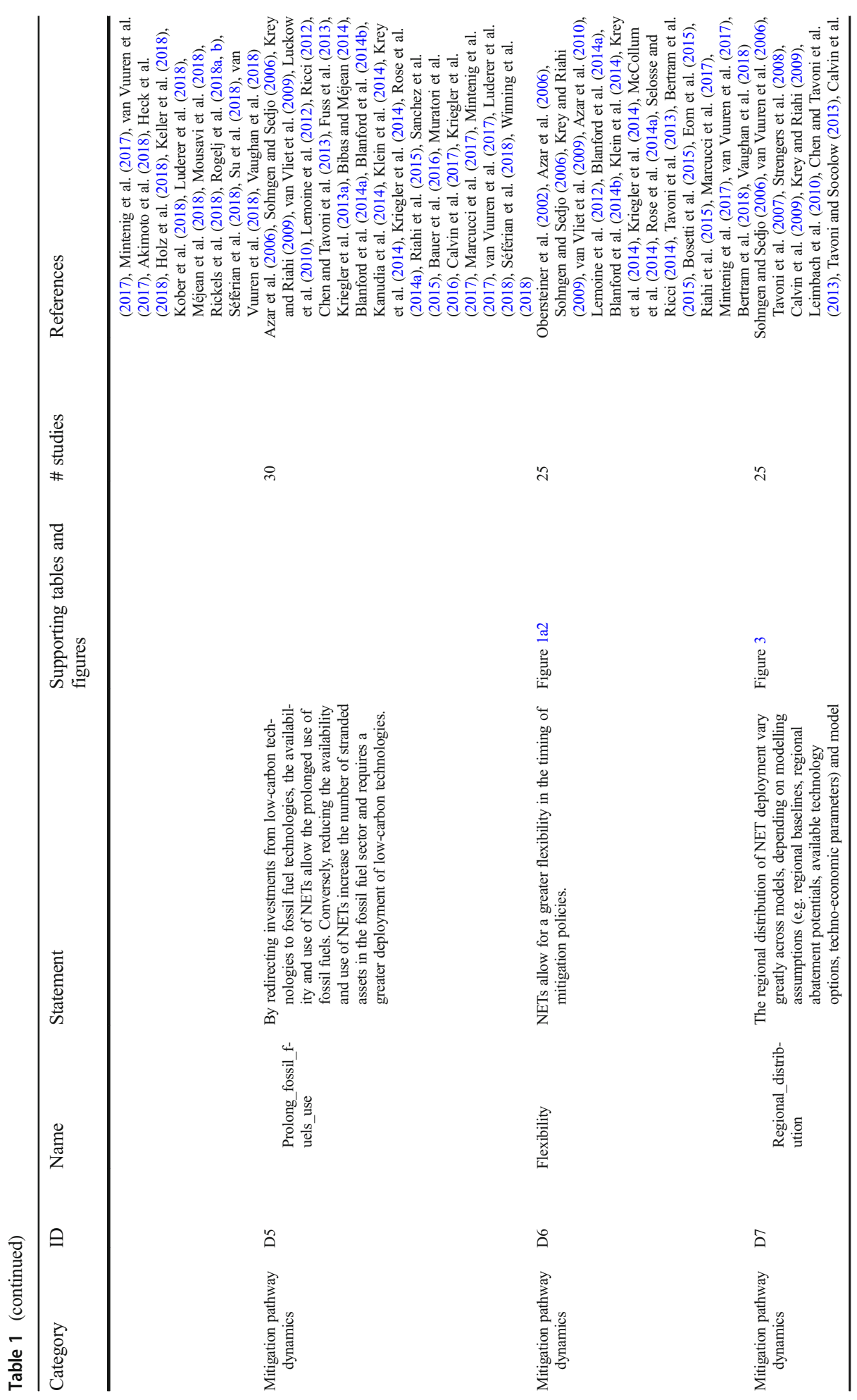




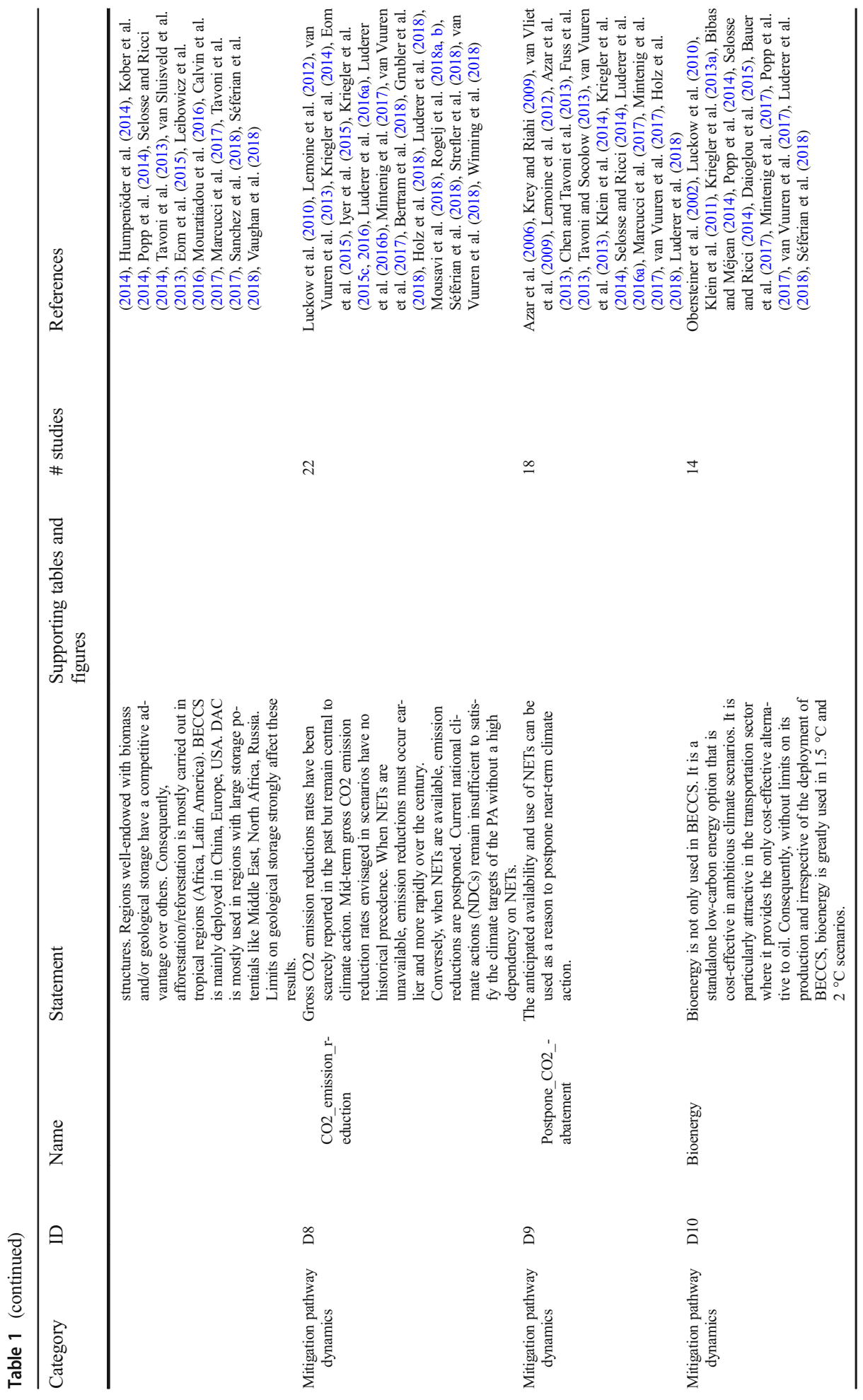




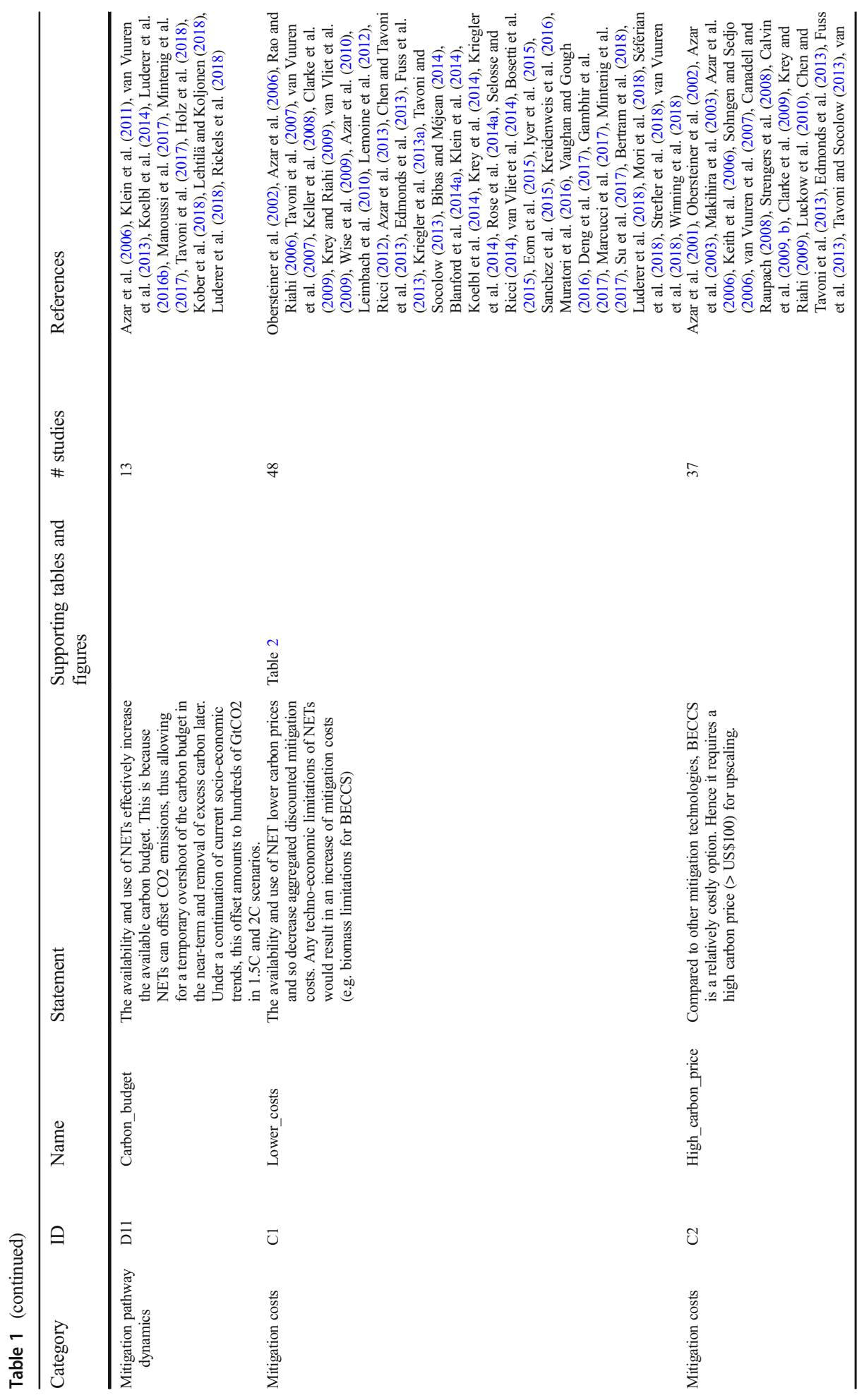




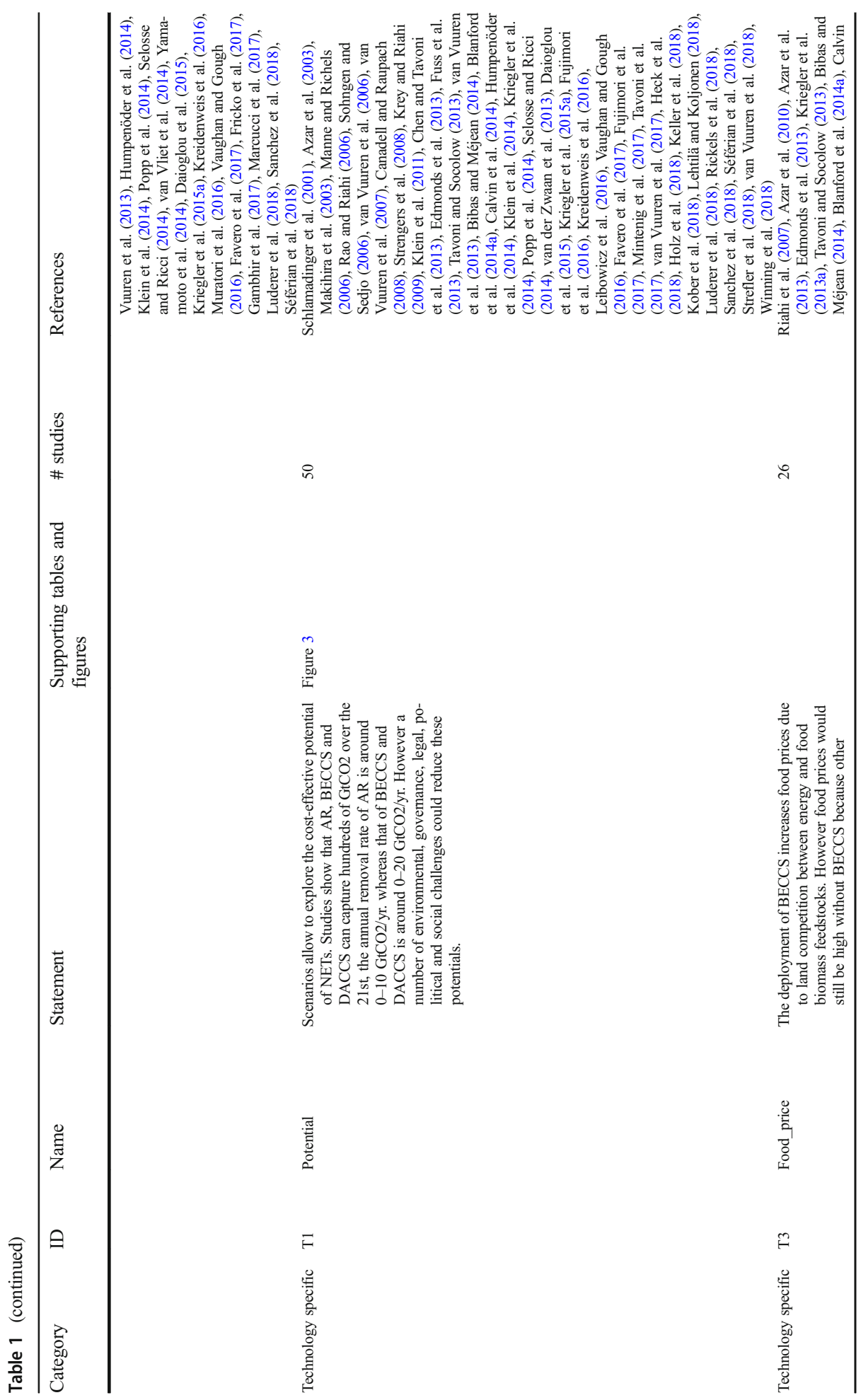




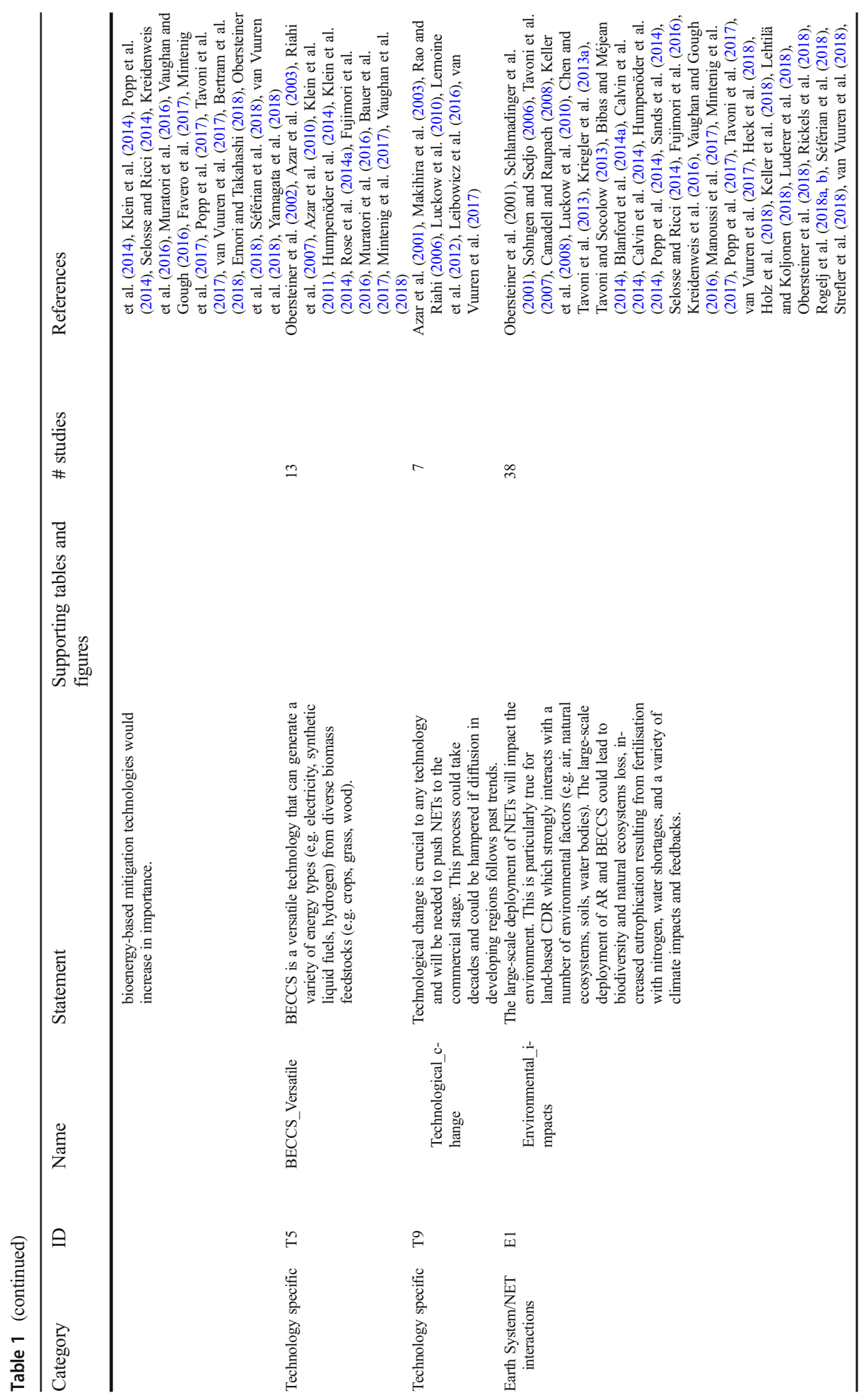




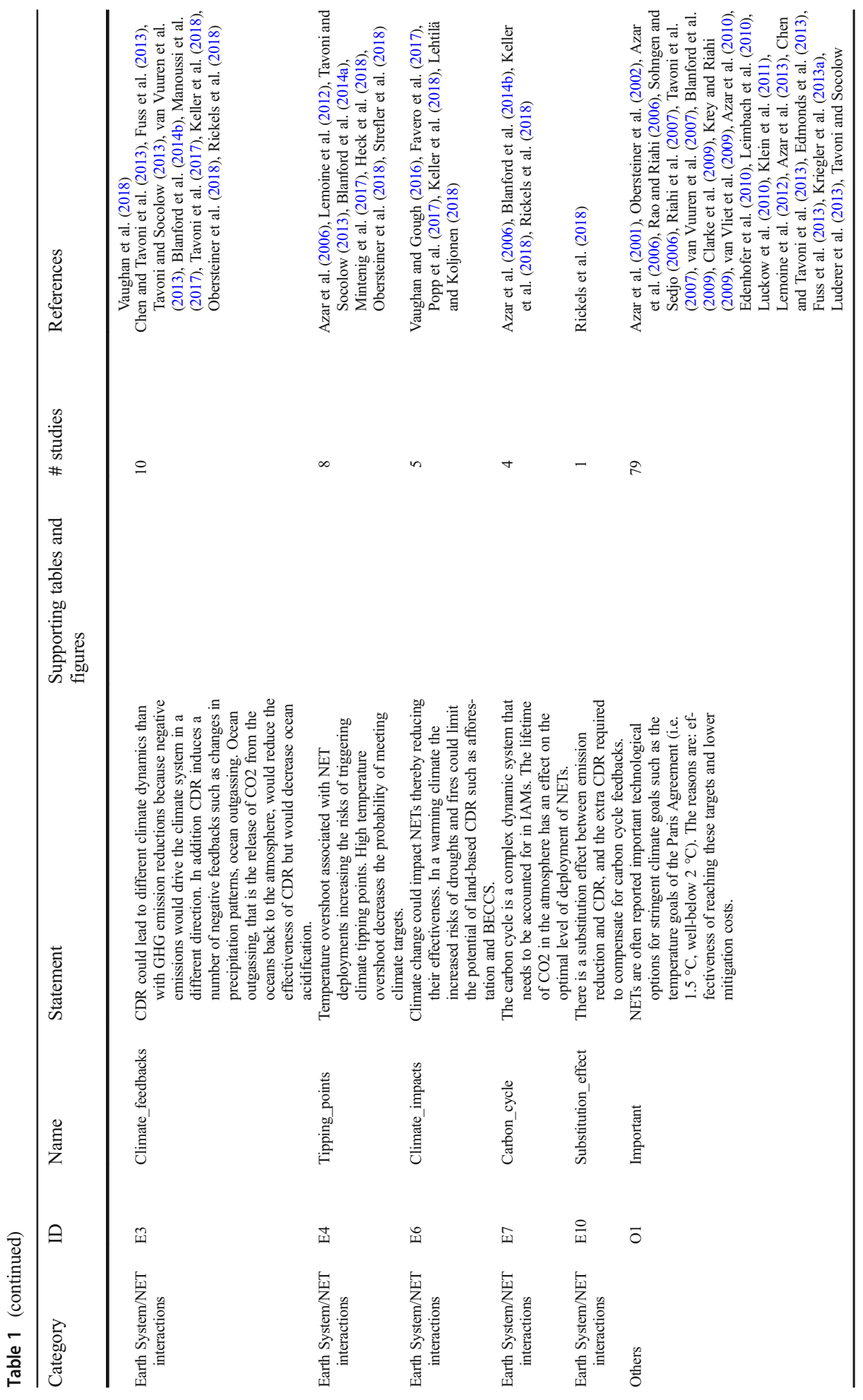




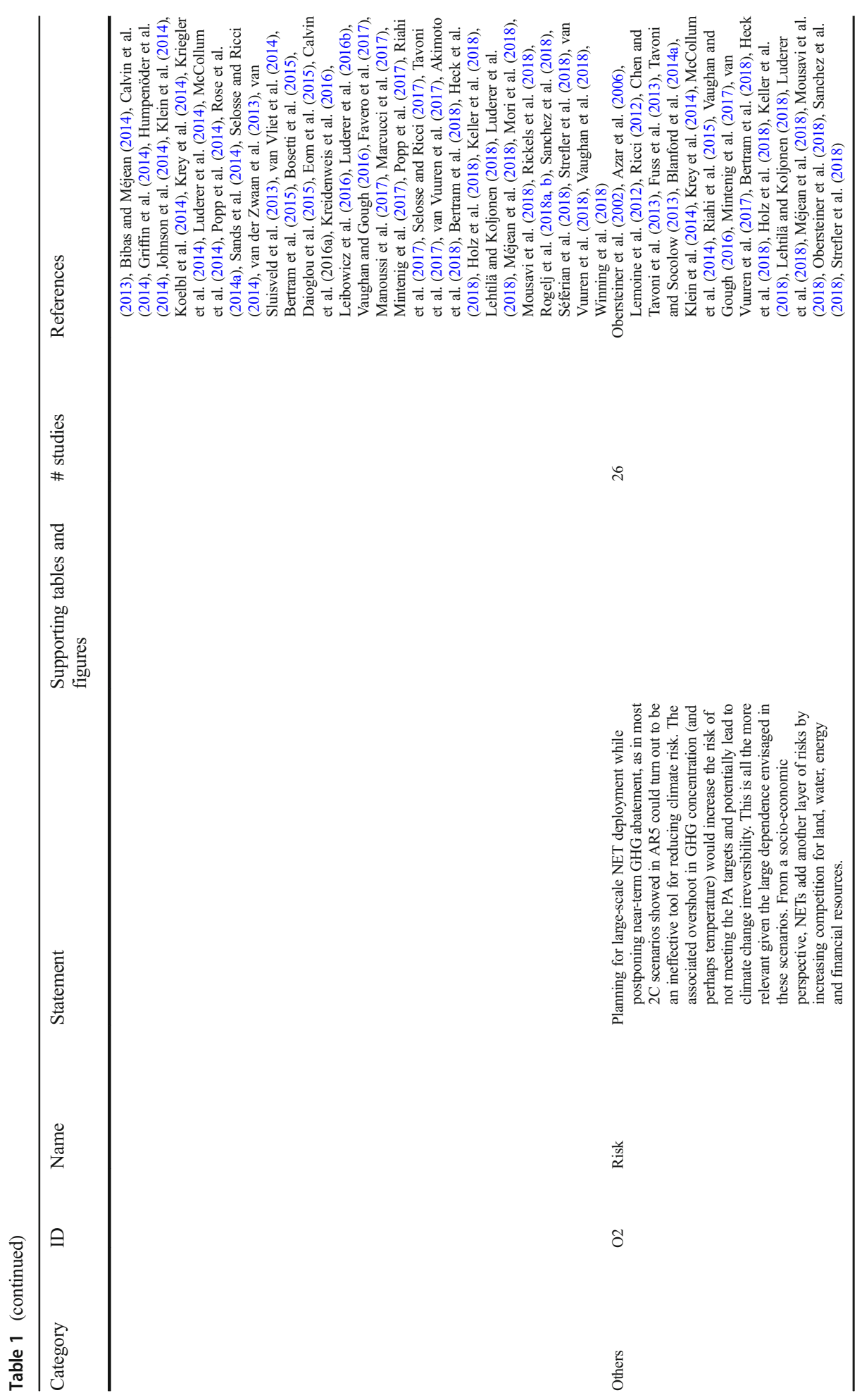




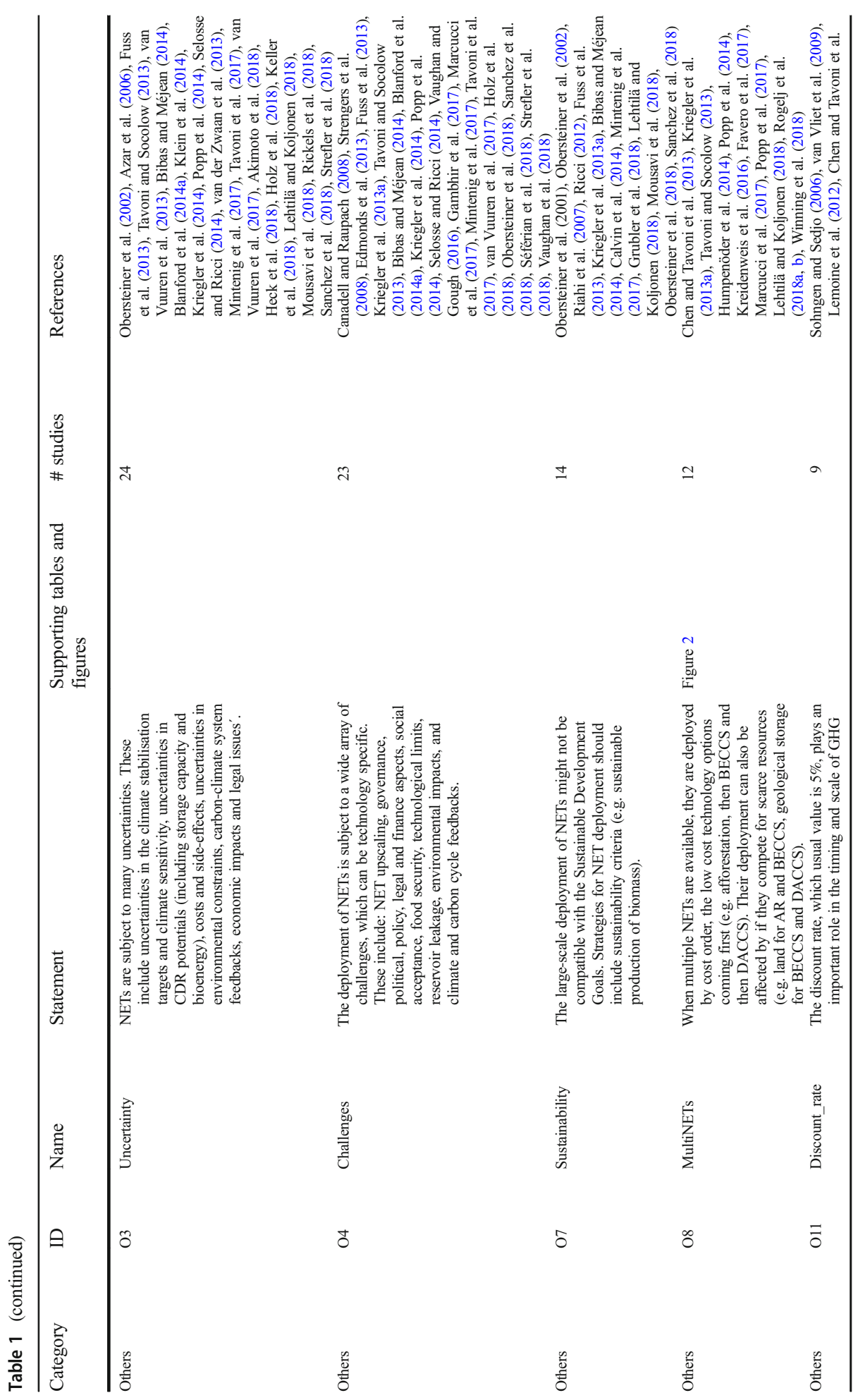




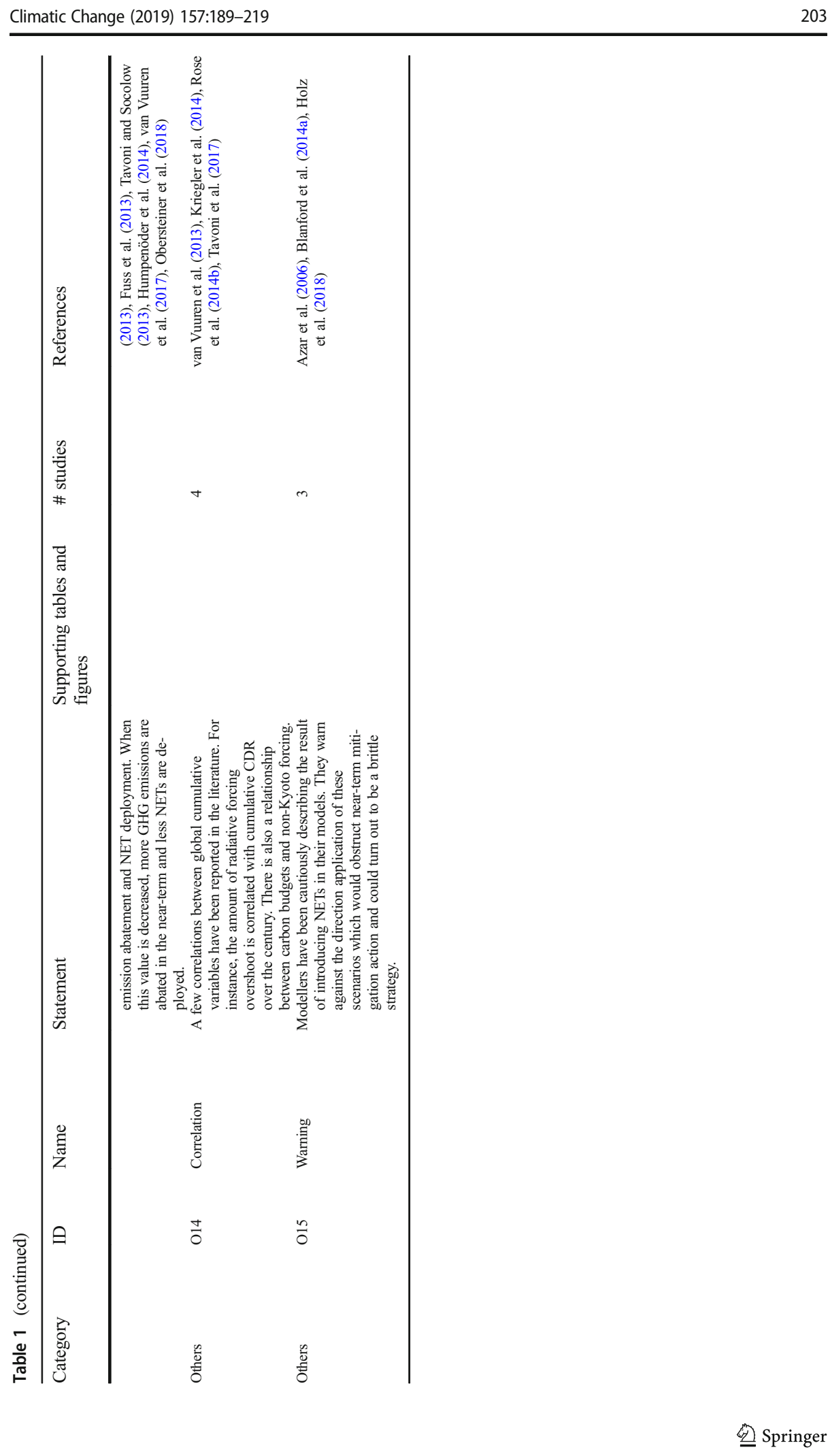


2050 occurs faster $\left(0.3[0.0-0.6] \mathrm{GtCO}_{2} /\right.$ year versus $0.2[0.0-0.4] \mathrm{GtCO}_{2} /$ year expansion $\left.{ }^{4}\right)$ unless climate policy is delayed until 2030 in $2{ }^{\circ} \mathrm{C}$ scenarios (Fig. 1a3, b2) D1. In fact, once climate action is delayed until 2030 , the negative emissions characteristics of $2{ }^{\circ} \mathrm{C}$ scenarios become increasingly similar to the $1.5^{\circ} \mathrm{C}$ scenarios with immediate action. It is worthwhile to note that this difference in NET reliance between 1.5 and $2{ }^{\circ} \mathrm{C}$ scenarios is predicated on estimates of the climate response that remain similar to the value assessed in AR5, despite recent studies showing the potential for possible changes to climate response (Millar et al. 2017; Tokarska and Gillett 2018).

The prominence of NETs in stringent climate mitigation scenarios is the product of two factors: geophysical requirements and economic incentives, which play very different roles in $1.5^{\circ} \mathrm{C}$ and $2{ }^{\circ} \mathrm{C}$ scenarios (Minx et al. 2018). As indicated earlier, while carbon dioxide removal deployment in $1.5^{\circ} \mathrm{C}$ scenarios is primarily driven by geophysical requirements - for compensating for the overshoot of the allowed carbon budget (Strefler et al. 2018; Kriegler et al. 2018b; Luderer et al. 2018) - this is not the case in $2{ }^{\circ} \mathrm{C}$ scenarios. Economic incentives however are an important feature of both $1.5^{\circ} \mathrm{C}$ and $2{ }^{\circ} \mathrm{C}$ scenarios as depicted by mitigation costs in Table 2. Mitigation costs are a good indicator for understanding the overall mitigation challenge in IAMs: as mitigation costs increase as models move towards their infeasibility frontier (Azar et al. 2006; Luderer et al. 2013). Moving across the columns of Table 2 shows how mitigation costs rise: (a) as long-term ambition increases and (b) as short-term emission reductions get delayed until 2030. Looking across the columns shows the decrease in mitigation costs as NETs are introduced into the models $\mathrm{C} 1$ and how models are driven to infeasibility in their absence, as short-term emission reductions get further delayed and longterm ambition increases O11. No single IAM study documents pathways without NETs returning warming to below $1.5^{\circ} \mathrm{C}$ by 2100 , or limiting warming to well below $2{ }^{\circ} \mathrm{C}$ after a delaying action until 2030.

The lowering of mitigation costs resulting from the deployment of NETs has far reaching consequences on mitigation pathways D2. Indeed, regardless of any geophysical requirement, the introduction of NETs in IAM curb emission reductions in the short run and compensates for the carbon budget overshoot towards the end century when carbon prices are high (often reaching thousands of US dollars per ton of $\mathrm{CO}_{2}$ ) D2, C2. For example, Fig. 1a2 demonstrates that, until 2060, median net $\mathrm{CO}_{2}$ emissions in $2{ }^{\circ} \mathrm{C}$ scenarios with BECCS exceeds that of the median $2{ }^{\circ} \mathrm{C}$ scenario without BECCS. Consequently, this temporal reallocation of $\mathrm{CO}_{2}$ emissions mitigation by NETs allow for more fossil fuel consumption in the near-term, thus leaving more time for the energy system transition, and a longer utilisation of existing infrastructure in the power, industry and building sectors D5.

Temporal discounting is the main factor driving these dynamics. Indeed, by giving a lower weight to the costs of future mitigation actions, the use of a constant discount rate (generally $5 \%$ ) during the twenty-first century makes the use of NETs in the second half of the century an economically attractive mitigation option that allow costly near-term emissions reductions to be postponed (van Vuuren et al. 2017; Obersteiner et al. 2018) D9. From these results, it is often concluded that NETs make the timing of climate mitigation policies more flexible D6. Aware of the potential misinterpretation of these findings, modellers described the risks, uncertainties and challenges in following such pathways $\mathrm{O} 2, \mathrm{O} 3, \mathrm{O} 4$, and have warned policy makers against postponing near-term abatement action $\mathrm{O} 14$.

\footnotetext{
${ }^{4}$ Values preceding the brackets are medians while those in the brackets are minima and maxima.
} 
By the end of the century, negative $\mathrm{CO}_{2}$ emissions from NETs compensate for past and current residual $\mathrm{CO}_{2}$ and non- $\mathrm{CO}_{2}$ emissions $\mathrm{D} 4$. Residual $\mathrm{CO}_{2}$ emissions can arise in the industry, buildings, transportation and land-use sectors and are a function of the ambition level of climate policy (Kriegler et al. 2018b; Luderer et al. 2018). They add to non- $\mathrm{CO}_{2}$ greenhouse gas (GHG) emissions like $\mathrm{CH}_{4}, \mathrm{~N}_{2} \mathrm{O}$ and F-Gases, which can represent a large share of total residual GHG emissions depending on the mitigation portfolio represented in models (Kober et al. 2014; Gernaat et al. 2015). When BECCS is available, the power sector is often reported to be essential for decarbonisation and to compensate for these residual emissions (van Sluisveld et al. 2013; Kriegler et al. 2013a). However, other sectors can in principle also contribute since BECCS is a versatile technology which can also be used to produce synthetic fuels, heat and hydrogen T5, O15.

Little attention has been given to portfolios of NETs in IAMs even though there is a growing number of studies that feature two or more NET options - most prominently BECCS and afforestation (AR) (Rao and Riahi 2006; Wise et al. 2009; Calvin et al. 2009a; Edmonds et al. 2013; Humpenöder et al. 2014; Bertram et al. 2018; van Vuuren et al. 2018; Grubler et al. 2018), but also BECCS and direct air capture with carbon sequestration (DACCS) (Chen and Tavoni et al. 2013; Marcucci et al. 2017) or BECCS and enhanced weathering (EW) (Strefler et al. 2015). More recently, Holz et al. (2018) produced scenarios with 6 NETs (i.e. AR, BECCS, biochar, DACCS, EW, soil carbon management). There are a few noticeable findings from these studies O8. Compared to scenarios featuring only BECCS, the availability and use of one or more additional NETs makes emission reductions in the near term even less attractive and further reduces the political costs of achieving the same climate policy objective D9, C1. Indeed, any addition of negative emission potential in scenarios results in an increase in total cumulative $\mathrm{CO}_{2}$ removal over the twenty-first century and further exacerbates the intertemporal trade-off explained in the previous paragraphs D4, D11. This increase in carbon removal occurs at decreasing rates because of substitution effects. Competition between NETs for land and/or geological storage reduces the individual potential of these technologies. For example, Humpenöder et al. (2014) who examine two land-based NETs (i.e. competing for scarce land) find that the amount of $\mathrm{CO}_{2}$ sequestered by BECCS over the 1995-2095 period decreases from 600 to $400 \mathrm{GtCO}_{2}$ when AR is added. Marcucci et al. (2017) find a lower effect of only a few gigatonnes between BECCS and DACCS, which compete for geological storage (see Fig. 2). Holz et al. (2018) also show that the contribution from AR is halved when 5 other NETs are added. These findings suggest that the availability of multiple NETs may help to better balance the various technology risks that are often scale dependent (Fuss et al. 2018). The degree to which this risk can be hedged depends however on technological competition.

Finally, while several studies have eliminated doubts that geological $\mathrm{CO}_{2}$ storage is a major limiting factor for NET deployment in $2{ }^{\circ} \mathrm{C}$ scenarios T1, this is less clear when NET deployment with geological $\mathrm{CO}_{2}$ storage further increase-like in $1.5^{\circ} \mathrm{C}$ scenarios and with the availability of additional NET options with geological storage like DACCS (Meinshausen et al. 2011; Dooley 2013; Edmonds et al. 2013; Tavoni and Socolow 2013; Vaughan and Gough 2016). Even though sequestration rate constraints can limit the amount of $\mathrm{CO}_{2}$ that can be stored annually, a meta-analysis concludes that $3900 \mathrm{GtCO}_{2}$ are "practically", available and

\footnotetext{
${ }^{5}$ In the geological $\mathrm{CO}_{2}$ storage pyramid (Bachu et al. 2007), "practical" storage capacity is a subset of the "effective" capacity. It includes storage sites that meet additional criteria (i.e. technical, legal and regulatory, infrastructure and general economic barriers to $\mathrm{CO}_{2}$ geological storage).
} 
$13,500 \mathrm{GtCO}_{2}$ are "effectively"6 available for storing carbon in onshore and offshore saline aquifers, depleted oil and gas fields, and deep "unmineable" coal basins (Dooley 2013). In a follow-up IAM analysis, Edmonds et al. (2013) made the assumption that $7000 \mathrm{GtCO}_{2}$ of storage would be available globally. We compare the regional estimates of these two studies to the available $1.5^{\circ} \mathrm{C}$ and $2{ }^{\circ} \mathrm{C}$ scenario data from the AMPERE (Kriegler et al. 2015b) and LIMITS (Kriegler et al. 2013b) projects (see Fig. 3). The geographical distribution of negative emissions reveals that BECCS is deployed globally (Calvin et al. 2009a; van Sluisveld et al. 2013; Edmonds et al. 2013) but particularly in regions with large biomass potential and/or large geological storage capacity such as USA, China, Former Soviet Union and Middle East D7. Interestingly, biomass trade allows regions without biomass but large geological storage like the Middle East to sequester carbon. This highlights the institutional challenges facing the large-scale deployment of BECCS. Technological change and financial requirements are also concerning particularly for developing countries ${ }^{7} \mathrm{~T} 9$. $^{2}$ Nonetheless large discrepancies exist not only in quantities of geological storage but also across model results. For instance, sequestered carbon in $2{ }^{\circ} \mathrm{C}$ scenarios can differ by more than 100 $\mathrm{GtCO}_{2}$ in Africa, Europe, Former Soviet Union, India, Latin America, Middle East, USA and up to $200 \mathrm{GtCO}_{2}$ in China. These differences are much smaller in $1.5^{\circ} \mathrm{C}$ scenarios because the results come from a single model. Differences can be attributed to model structures (e.g. general equilibrium model vs partial equilibrium model, regional resolution, etc.) and (regional) modelling assumptions (e.g. geological storage potential, biomass potential, etc.) which can be more or less optimistic about implementable potentials given political, institutional and social acceptancerelated constraints $\mathrm{O} 4$. It should be noted that IAMs use different estimates of geological storage. For instance, geological storage constraints in Marcucci et al. (2017) are based on Hendriks et al. (2004) whereas estimates used in GCAM are based on Dooley (2013) and Edmonds et al. (2014). In IMAGE, upper limits on geological storage are also based on Hendriks et al. (2004) with updates from Koelbl (2016).

\section{Discussion and outlook}

IAMs have played a central role in expanding the research frontiers of NETs and helping to discover policy-relevant findings about these technologies. Yet, qualitative evidence so far has not been adequately aggregated into a traceable and updatable body of knowledge and has been disconnected from reviews of quantitative evidence based on large scenario ensembles. In this study, we close this gap by systematically reviewing individual findings in a thematic synthesis of the underlying literature (Boyatzis 1998; Guest et al. 2012) connecting them explicitly to the quantitative ensemble evidence. We argue that such synthesis that systematically connects qualitative and quantitative evidence has been missing so far and impeded a comprehensive and transparent assessment of the role of NETs in climate change mitigation in previous IPCC reports. As such, this paper can help to establish a comprehensive and traceable account of evidence for upcoming IPCC AR6 that can be easily updated.

Table 1 provides an overview of the findings identified during our review. We emphasise that one should not interpret any statement omitted in the previous section as less significant.

\footnotetext{
${ }^{6}$ Here, "effectively" refers to storage sites that satisfy a range of basic geological and engineering conditions which can be quantified with a fair degree of confidence

${ }^{7}$ The financial requirements of other climate change mitigation technologies in developing countries are also of great concern. This is the case for wind and solar capacities for instance (Hirth and Steckel 2016).
} 


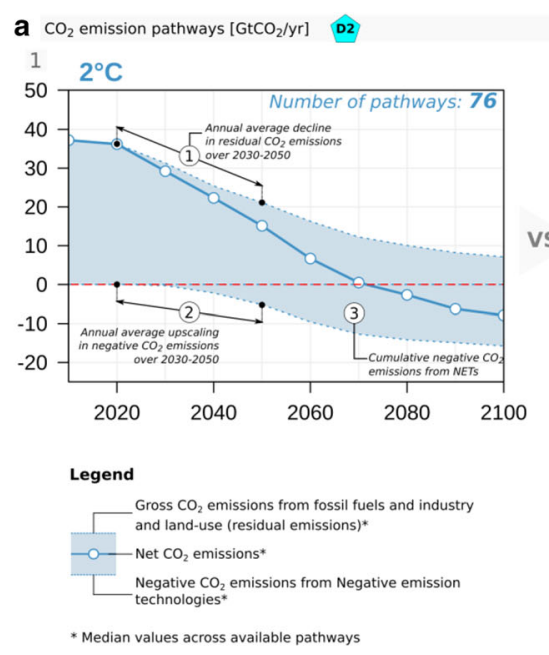

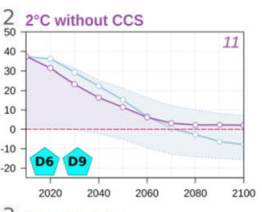

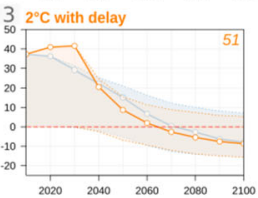

$42^{\circ} \mathrm{C}$ under SSP5
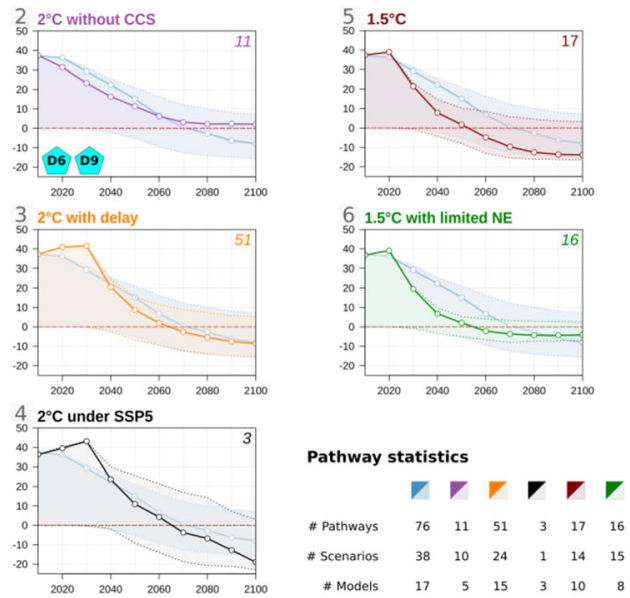

b Statistics of key NETs metrics
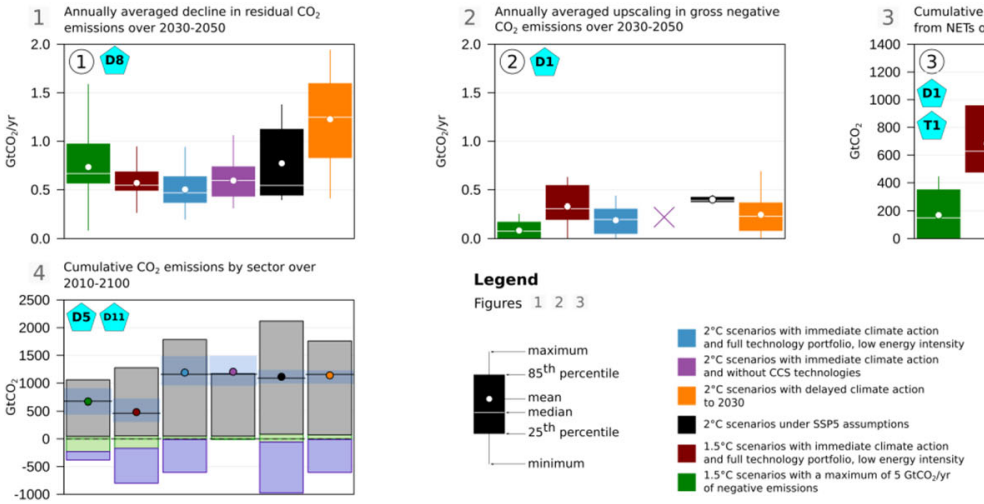

Fig. 1 The role of NETs in meeting international climate targets under various technological and policy constraints and societal choices. Part B shows key statistics. The number of pathways, models and scenarios are provided in Figure 1a. The colour scheme used to differentiate scenario categories in Figures 1a and $\mathbf{1 b}$ are the same that is blue for $2{ }^{\circ} \mathrm{C}$ pathways with immediate action and full technology, purple for $2{ }^{\circ} \mathrm{C}$ pathways without CCS technology, orange for $2{ }^{\circ} \mathrm{C}$ pathways with delayed action to 2030 , black for $2{ }^{\circ} \mathrm{C}$ pathways under SSP5 assumptions, red for $1.5^{\circ} \mathrm{C}$ pathways with immediate action and full technology and green for $1.5^{\circ} \mathrm{C}$ pathways with limited $\mathrm{CDRavailability}\left(<5 \mathrm{GtCO}_{2} /\right.$ year). The cyan pentagons refer to the qualitative findings in Table 1

Instead we selected statements according to the focus of this review, i.e. the role of NETs in $1.5^{\circ} \mathrm{C}$ and $2{ }^{\circ} \mathrm{C}$ scenarios, respectively. As such, it serves as a template for bridging qualitative and quantitative evidence systematically. For example, we did not discuss the role that BECCS can play in increasing food prices T3. Although the large-scale deployment of BECCS requires hundreds of millions of hectares to grow bioenergy T1, food prices would still be high in a world without BECCS because bioenergy would increase in importance as a mitigation technology ${ }^{8}$ D10. Similar choices will be required in upcoming climate change assessments that are inherently space constrained. The key point here is that comprehensive, traceable accounts of both quantitative and qualitative evidence are required to do make informed and transparent choices in this process (Huppmann et al. 2018). 
Table 2 The role of NETs in decreasing mitigation costs. Mitigation costs are the discounted sum of all costs associated with climate mitigation action over the period 2010-2100, calculated here for a $67 \%$ confidence level of limiting warming to below $2{ }^{\circ} \mathrm{C}$ (well below $2{ }^{\circ} \mathrm{C}$ case), or a $50 \%$ confidence level of limiting end of century warming to $1.5^{\circ} \mathrm{C}$ by interpolating between respective scenarios. Red crosses indicate infeasible scenarios. Costs represent discounted and aggregated consumption losses (i.e. differences in consumption between a baseline and a climate policy scenario) as a share of discounted and aggregated GDP (in the climate policy scenario). A discount rate of 5\% is used. Results adapted from Luderer et al. (2013)

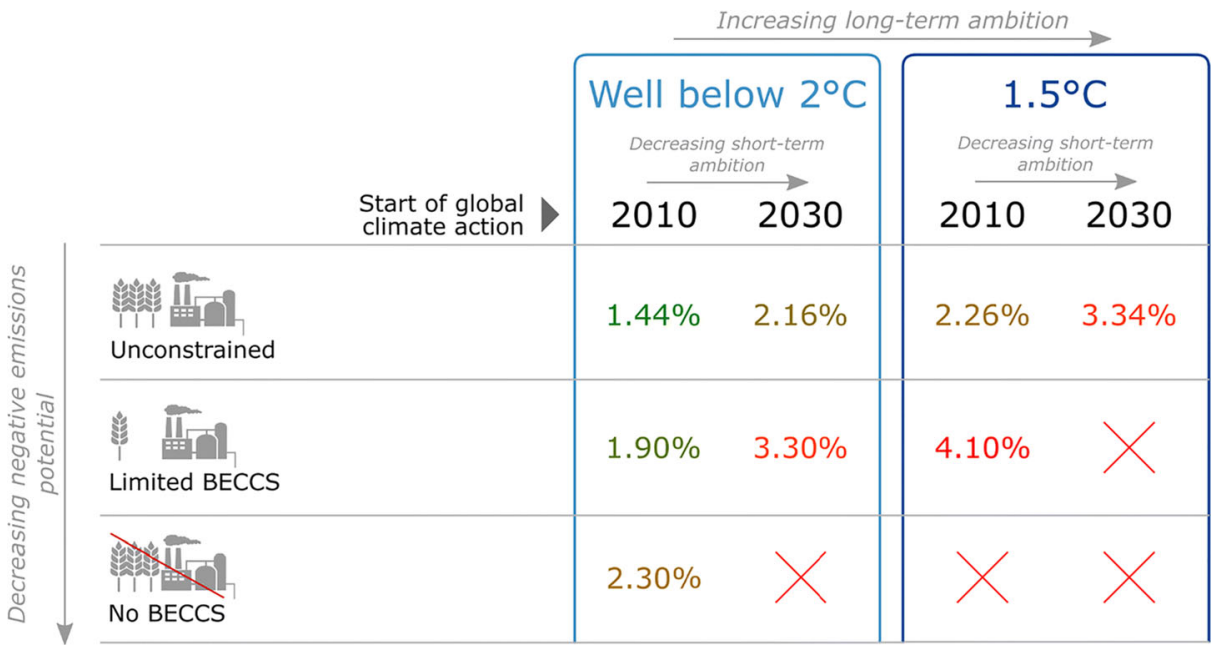

Our approach could be extended in the future. First, it does not represent the entire universe of scenarios on climate change mitigation. A more comprehensive identification and selection of qualitative evidence based on a structured search in bibliographic databases such as Web of Science or Scopus could be a first step in addressing the longstanding concern of selection bias in IPCC assessments of scenario evidence (Haddaway and Macura, 2018). Second, although we are confident that our table of statements includes the major findings of the literature, our search could be extended to capture more peripheral topics (e.g. geological storage, food price). Third, our compiled scenario database contains important data gaps as all model output is not consistently made available publicly. This selection could introduce biases in our numerical results due to model and scenario design sampling. More comprehensive reporting and data provision requirements seem crucial. The qualitative findings presented here however are in good agreement with the list of major statements from the literature. Fourth, while our assessment can robustly identify and reflect insights from the available scenario literature on NETs, it is much harder to identify whether any pervasive scenario assumptions might bias these statements in a particular direction, and whether there are specific conditions under which these insights would apply.

Despite these shortcomings, synthetic research efforts within the scientific community like this study are increasingly valuable (Kowarsch et al. 2016, 2017), particularly in times of exponentially growing scientific publications on climate change (Grieneisen and Zhang 2011;

\footnotetext{
${ }^{0}$ The importance of bioenergy may decrease in future scenarios if the deployment of electric vehicles continues to gather momentum worldwide.
} 


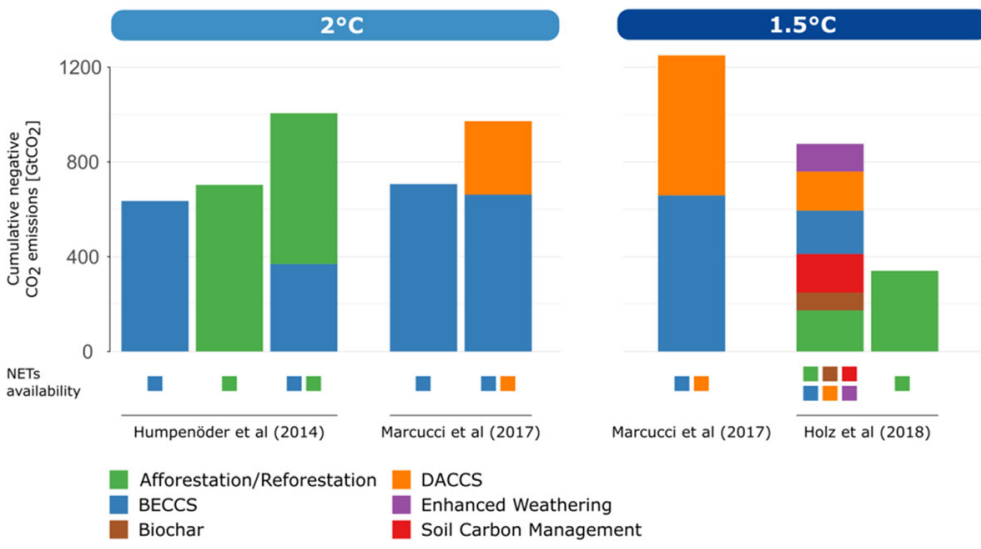

Fig. 2 The role of small NET portfolios in meeting the $1.5^{\circ} \mathrm{C}$ and $2{ }^{\circ} \mathrm{C}$ climate goals. Each bar represents a scenario. NET availability is indicated by a small square below the bars. Data from Humpenöder et al. (2014) are cumulated over 1995-2095 while that of Marcucci et al. (2017) and Holz et al. (2018) are cumulated over 20102100

Haunschild et al. 2016; Minx et al. 2017b). Not engaging in such efforts could exacerbate the difficulty for assessment bodies like the IPCC to meet their often ambitious mandates (Minx et al. 2017a). While such computer-assisted synthetic methods (Westgate et al. 2018; Nakagawa et al. 2018; Lamb et al. 2019) still require laborious inputs from and verification by humans, it allows for a more efficient and better evaluation of the veracity of findings by linking them directly to supporting studies. It may also reduce the risk of bias and misinterpretations by policymakers, who would be in a better position to confront arguments based on cherry-picking and infrequently-made claims.

Importantly, this review allowed us to identify important research gaps, some of which have been underscored in Fuss et al. (2018) and Rogelj et al. (2018b). First, it seems

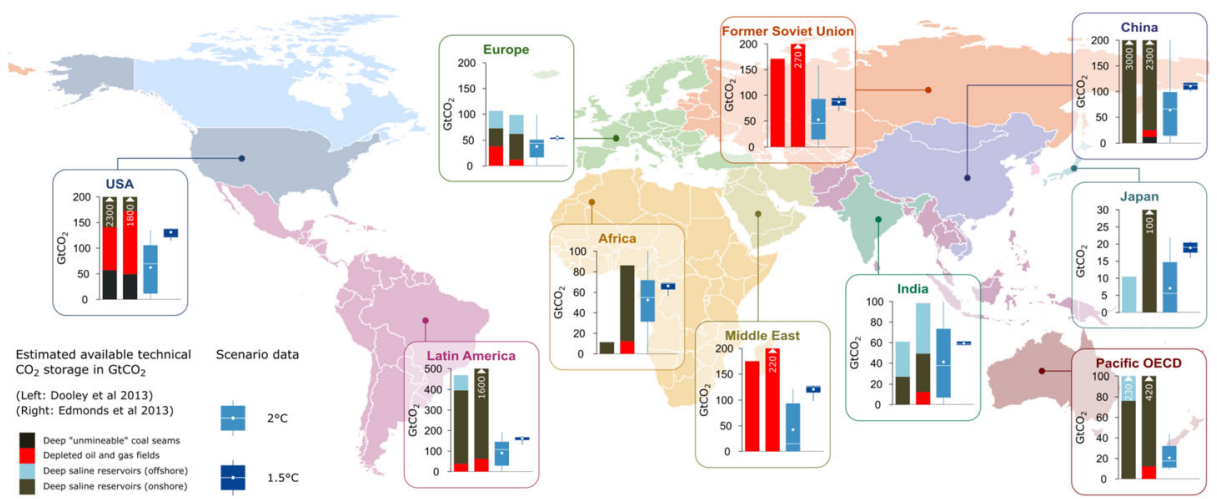

Fig. 3 Regional geological $\mathrm{CO}_{2}$ storage capacity and $\mathrm{CO}_{2}$ sequestered by BECCS. Geological $\mathrm{CO}_{2}$ storage data correspond to the "practical" category from Dooley (2013) which totals $3900 \mathrm{GtCO}_{2}$ (left bar) and the modified version by Edmonds et al. (2013) which totals $7000 \mathrm{GtCO}_{2}$ (right bar). Scenario data are from AMPERE (Kriegler et al. 2015a, b, c), LIMITS (Kriegler et al. 2013a, 2013b), RoSE (Kriegler et al. 2016) and Luderer et al. (2013). Scenario data for Canada and Southeast Asia were missing and so could not be included here. Similarly $1.5^{\circ} \mathrm{C}$ scenarios for the Pacific OECD region are unavailable 
crucial to better understand large NET deployments frequently observed in the literature (Fuss et al. 2018; Rogelj et al. 2018b). Initial evidence suggests that this is directly related to the cost-effectiveness framework (and discount rate) underlying the models studied here, and that, even though CDR would also be large in a cost-risk analysis (Mintenig et al. 2017), a consideration of climate impacts in a cost-benefit mode would substantially decrease CDR deployments (Blanford 2013). Since climate impacts could also affect the potential of NETs, accounting for these effects in IAMs would allow identifying important trade-offs and provide additional insights on the optimal timing and levels of NETs (Rogelj et al. 2018b) E3, E4, E6, E7, E10. Second, as the wider discourse on NETs highlights that even some of the more modest deployment levels are unlikely to be reached with BECCS as a single NET, a deeper exploration of NET portfolios and their ability to hedge against some of the deployment risks are crucial O8. This would also require further exploring the adequacy of introducing NETs that have been neglected ${ }^{9}$ by the IAM community so far (e.g. blue carbon) as well as the synergies and trade-offs between NETs. Third, considering and understanding what benefits, risks and societal trade-offs these options could provide would be important. A number of recent studies have also highlighted the potential role of non- $\mathrm{CO}_{2}$ GHG removal technologies (Stolaroff et al. 2012; Lomax et al. 2015; Ming et al. 2016; de Richter et al. 2016, 2017). A large fraction of residual emissions at the end of the century come from non- $\mathrm{CO}_{2} \mathrm{GHG}$, some of which are stock pollutants that accumulate in the atmosphere. For these species, GHG removal appears a promising avenue for future research. Fourth, not only do large-scale deployments of NETs impact regional economies, energy systems and carbon budgets but they can also lead to food price increases (Wise et al. 2009; Calvin et al. 2009a; Reilly et al. 2012; Kreidenweis et al. 2016), local air and water pollution, water overuse and biodiversity losses (Williamson 2016) T3, E1. Consequently, NETs should be examined under a broader spectrum of societal and environmental goals. To that end, Planetary Boundaries and Sustainable Development Goals provide useful frameworks for future research E8, O7. Finally, net negative $\mathrm{CO}_{2}$ emissions, which could amount to a few tens of gigatonnes of $\mathrm{CO}_{2}$ by the end of century when carbon prices are high, would require substantive and sustained support from financing bodies (e.g. governments) O4. In an intertemporal optimisation framework, this can be financed by a banking and borrowing scheme. However, whether such large-scale financing product could see the light in reality is unclear at the moment. Therefore, it would be essential to investigate the role of NETs in an intergenerational modelling framework and from a political and business perspective.

Acknowledgements We would like to thank Adriana Marcucci for providing the MERGE-ETL data underlying Fig. 3, Christian Holz for providing the C-ROADS data used in Figs. 1 and 3, Detlef van Vuuren and Mathijs Harmsen for providing the IMAGE data used in Fig. 1, and Ulf Weddige for his support in helping producing Fig. 2. JH has conducted the work for this article in the frame of the project "Pathways and Entry Points to limit global warming to $1.5^{\circ} \mathrm{C}$ " funded by the German Ministry of Research and Education (Grant reference: 01LS1610B). J.M. further contributed to this article under the Project "Strategic Scenario Analysis" (START) funded by the German Ministry of Research and Education (Grant reference: 03EK3046B).

Open Access This article is distributed under the terms of the Creative Commons Attribution 4.0 International License (http://creativecommons.org/licenses/by/4.0/), which permits unrestricted use, distribution, and reproduction in any medium, provided you give appropriate credit to the original author(s) and the source, provide a link to the Creative Commons license, and indicate if changes were made.

$\overline{9}$ An exception is Holz et al. (2018) 


\section{References}

Aboumahboub T, Luderer G, Kriegler E et al (2014) On the regional distribution of climate mitigation costs: the impact of delayed cooperative action. Climate Change Economics 05:1440002-1440002. https:/doi. org/10.1142/S2010007814400028

Akimoto K, Sano F, Tomoda T (2018) GHG emission pathways until 2300 for the $1.5^{\circ} \mathrm{C}$ temperature rise target and the mitigation costs achieving the pathways. Mitig Adapt Strateg Glob Chang 23:839-852. https:/doi. org/10.1007/s11027-017-9762-z

Anderson K (2015) Duality in climate science. Nat Geosci 8:ngeo2559. https://doi.org/10.1038/ngeo2559

Anderson K, Peters G (2016) The trouble with negative emissions. Science 354:182-183. https://doi.org/10.1126 /science.aah4567

Azar C, Lindgren K, Persson T (2001) Carbon sequestration from fossil fuels and biomass - long-term potentials. Göteborg

Azar C, Lindgren K, Andersson BA (2003) Global energy scenarios meeting stringent CO2 constraints- costeffective fuel choices in the transportation sector. Energy Policy 31:961-976. https://doi.org/10.1016/S03014215(02)00139-8

Azar C, Lindgren K, Larson E, Möllersten K (2006) Carbon capture and storage from fossil fuels and biomass costs and potential role in stabilizing the atmosphere. Clim Chang 74:47-79. https://doi.org/10.1007/s10584005-3484-7

Azar C, Lindgren K, Obersteiner M et al (2010) The feasibility of low CO2 concentration targets and the role of bio-energy with carbon capture and storage (BECCS). Clim Chang 100:195-202. https://doi.org/10.1007 /s10584-010-9832-7

Azar C, Johansson DJA, Mattsson N (2013) Meeting global temperature targets - the role of bioenergy with carbon capture and storage. Environ Res Lett 8:034004. https://doi.org/10.1088/1748-9326/8/3/034004

Bachu S, Bonijoly D, Bradshaw J et al (2007) CO2 storage capacity estimation: methodology and gaps. Int J Greenh Gas Con 1:430-443. https://doi.org/10.1016/S1750-5836(07)00086-2

Bauer N, Mouratiadou I, Luderer G et al (2016) Global fossil energy markets and climate change mitigation - an analysis with REMIND. Clim Chang 136:69-82. https://doi.org/10.1007/s10584-013-0901-6

Bauer N, Calvin K, Emmerling J et al (2017) Shared socio-economic pathways of the energy sector - quantifying the narratives. Glob Environ Chang 42:316-330. https://doi.org/10.1016/j.gloenvcha.2016.07.006

Bauer N, Rose SK, Fujimori S et al (2018) Global energy sector emission reductions and bioenergy use: overview of the bioenergy demand phase of the EMF-33 model comparison. Clim Chang:1-16. https://doi.org/10.1007/s10584-018-2226-y

Bertram C, Johnson N, Luderer G et al (2015) Carbon lock-in through capital stock inertia associated with weak near-term climate policies. Technol Forecast Soc Chang 90(Part A):62-72. https://doi.org/10.1016/j. techfore.2013.10.001

Bertram C, Luderer G, Popp A et al (2018) Targeted policies can compensate most of the increased sustainability risks in $1.5^{\circ} \mathrm{C}$ mitigation scenarios. Environ Res Lett 13:064038. https://doi.org/10.1088/1748-9326/aac3ec

Bibas R, Méjean A (2014) Potential and limitations of bioenergy for low carbon transitions. Clim Chang 123: 731-761. https://doi.org/10.1007/s10584-013-0962-6

Blanford G (2013) Is overshoot optimal? Negative emissions in a cost-benefit setting. Toulouse, France

Blanford GJ, Richels RG, Rutherford TF (2009) Feasible climate targets: the roles of economic growth, coalition development and expectations. Energy Econ 31(Supplement 2):S82-S93. https://doi.org/10.1016/j. eneco.2009.06.003

Blanford G, Merrick J, Richels R, Rose S (2014a) Trade-offs between mitigation costs and temperature change. Clim Chang 1-15. doi: https://doi.org/10.1007/s10584-013-0869-2

Blanford GJ, Kriegler E, Tavoni M (2014b) Harmonization vs. fragmentation: overview of climate policy scenarios in EMF27. Clim Chang. https://doi.org/10.1007/s10584-013-0951-9

Bosetti V, Marangoni G, Borgonovo E et al (2015) Sensitivity to energy technology costs: a multi-model comparison analysis. Energy Policy 80:244-263. https://doi.org/10.1016/j.enpol.2014.12.012

Bowen A, Campiglio E, Tavoni M (2014) A macroeconomic perspective on climate change mitigation: meeting the financing challenge. Climate Change Economics 05:1440005-1440005. https://doi.org/10.1142 /S2010007814400053

Boyatzis RE (1998) Transforming qualitative information. SAGE Publishing

Bruckner T, Bashmakov IA, Mulugetta Y, et al (2014) Energy Systems. In: Edenhofer O, Pichs-Madruga R, Sokona Y, et al. (eds) Climate change 2014: mitigation of climate change. Contribution of Working Group III to the Fifth Assessment Report of the Intergovernmental Panel on Climate Change. Cambridge University Press, Cambridge, United Kingdom and New York, NY, USA

Calvin K, Edmonds J, Bond-Lamberty B et al (2009) 2.6: limiting climate change to 450 ppm CO2 equivalent in the 21st century. Energy Econ 31:S107-S120. https://doi.org/10.1016/j.eneco.2009.06.006 
Calvin K, Pachauri S, Cian ED, Mouratiadou I (2013a) The effect of African growth on future global energy, emissions, and regional development. Clim Chang:1-17. https://doi.org/10.1007/s10584-013-0964-4

Calvin K, Wise M, Klein D et al (2013b) A multi-model analysis of the regional and sectoral roles of bioenergy in near- and long-term CO2 emissions reductions. Climate Change Economics 04:1340014-1340014. https://doi.org/10.1142/S2010007813400149

Calvin K, Wise M, Kyle P et al (2014) Trade-offs of different land and bioenergy policies on the path to achieving climate targets. Clim Chang 123:691-704. https://doi.org/10.1007/s10584-013-0897-y

Calvin K, Bond-Lamberty B, Clarke L et al (2017) The SSP4: a world of deepening inequality. Glob Environ Chang 42:284-296. https://doi.org/10.1016/j.gloenvcha.2016.06.010

Canadell JG, Raupach M (2008) Managing forests for climate change mitigation. Science 320:1456-1457. https://doi.org/10.1126/science. 1155458

Chen C, Tavoni M (2013) Direct air capture of CO2 and climate stabilization: a model based assessment. Clim Chang 118:59-72. https://doi.org/10.1007/s10584-013-0714-7

Clarke L, Edmonds J, Krey V et al (2009) International climate policy architectures: overview of the EMF 22 international scenarios. Energy Econ 31:S64-S81. https://doi.org/10.1016/j.eneco.2009.10.013

Clarke L, Jiang K, Akimoto K, et al (2014) Assessing transformation pathways. In: Edenhofer O, Pichs-Madruga R, Sokona Y, et al. (eds) Climate change 2014: mitigation of climate change. Contribution of Working Group III to the Fifth Assessment Report of the Intergovernmental Panel on Climate Change. Cambridge University Press, Cambridge, United Kingdom and New York, NY, USA

Daioglou V, Wicke B, Faaij APC, van Vuuren DP (2015) Competing uses of biomass for energy and chemicals: implications for long-term global CO2 mitigation potential. GCB Bioenergy 7:1321-1334. https:/doi. org/10.1111/gcbb.12228

de Coninck H, Revi A, Babiker M et al (2018) Strengthening and implementing the global response. In: Global warming of $1.5^{\circ} \mathrm{C}$. An IPCC Special Report on the impacts of global warming of $1.5^{\circ} \mathrm{C}$ above pre-industrial levels and related global greenhouse gas emission pathways, in the context of strengthening the global response to the threat of climate change, sustainable development, and efforts to eradicate poverty [MassonDelmotte, V., P. Zhai, H.-O. Pörtner, D. Roberts, J. Skea, P.R. Shukla, A. Pirani, W. Moufouma-Okia, C. Péan, R. Pidcock, S. Connors, J.B.R. Matthews, Y. Chen, X. Zhou, M.I. Gomis, E. Lonnoy, T. Maycock, M. Tignor, and T. Waterfield (eds.)]. In Press

de Richter RK, Ming T, Caillol S, Liu W (2016) Fighting global warming by GHG removal: destroying CFCs and HCFCs in solar-wind power plant hybrids producing renewable energy with no-intermittency. International Journal of Greenhouse Gas Control 49:449-472. https://doi.org/10.1016/j.ijggc.2016.02.027

de Richter R, Ming T, Davies P et al (2017) Removal of non-CO2 greenhouse gases by large-scale atmospheric solar photocatalysis. Prog Energy Combust Sci 60:68-96. https://doi.org/10.1016/j.pecs.2017.01.001

Deng H, Bielicki JM, Oppenheimer M et al (2017) Leakage risks of geologic CO2 storage and the impacts on the global energy system and climate change mitigation. Clim Chang 144:151-163. https://doi.org/10.1007 /s10584-017-2035-8

Dooley JJ (2013) Estimating the supply and demand for deep geologic CO2 storage capacity over the course of the 21 st century: a meta-analysis of the literature. Energy Procedia 37:5141-5150. https://doi.org/10.1016/j. egypro.2013.06.429

Edenhofer O, Knopf B, Barker T et al (2010) The economics of low stabilization: model comparison of mitigation strategies and costs. Energy J 31:11-48. https://doi.org/10.5547/ISSN0195-6574-EJ-Vol31NoSI-2

Edmonds J, Luckow P, Calvin K et al (2013) Can radiative forcing be limited to $2.6 \mathrm{Wm}-2$ without negative emissions from bioenergy AND CO2 capture and storage? Clim Chang 118:29-43. https://doi.org/10.1007 /s10584-012-0678-z

Emori S, Takahashi K (2018) Integrated climate assessment: risks, uncertainties, and society. Sustain Sci 13:275277. https://doi.org/10.1007/s11625-018-0539-4

Eom J, Edmonds J, Krey V et al (2015) The impact of near-term climate policy choices on technology and emission transition pathways. Technol Forecast Soc Chang 90(Part A):73-88. https://doi.org/10.1016/j. techfore.2013.09.017

Favero A, Mendelsohn R, Sohngen B (2017) Using forests for climate mitigation: sequester carbon or produce woody biomass? Clim Chang 144:195-206. https://doi.org/10.1007/s10584-017-2034-9

Field CB, Mach KJ (2017) Rightsizing carbon dioxide removal. Science 356:706-707. https://doi.org/10.1126 /science.aam9726

Fricko O, Havlik P, Rogelj J et al (2017) The marker quantification of the shared socioeconomic pathway 2: a middle-of-the-road scenario for the 21st century. Glob Environ Chang 42:251-267. https://doi.org/10.1016/j. gloenvcha.2016.06.004

Fujimori S, Su X, Liu J-Y et al (2016) Implication of Paris agreement in the context of long-term climate mitigation goals. SpringerPlus 5:1620-1620. https://doi.org/10.1186/s40064-016-3235-9 
Fujimori S, Hasegawa T, Masui T et al (2017) SSP3: AIM implementation of shared socioeconomic pathways. Glob Environ Chang 42:268-283. https://doi.org/10.1016/j.gloenvcha.2016.06.009

Fuss S, Reuter WH, Szolgayová J, Obersteiner M (2013) Optimal mitigation strategies with negative emission technologies and carbon sinks under uncertainty. Clim Chang 118:73-87. https://doi.org/10.1007/s10584012-0676-1

Fuss S, Canadell JG, Peters GP et al (2014) Betting on negative emissions. Nat Clim Chang 4:850-853. https://doi.org/10.1038/nclimate2392

Fuss S, Lamb WF, Callaghan MW et al (2018) Negative emissions-part 2: costs, potentials and side effects. Environ Res Lett 13:063002. https://doi.org/10.1088/1748-9326/aabf9f

Gambhir A, Drouet L, McCollum D et al (2017) Assessing the feasibility of global long-term mitigation scenarios. Energies 10:89-89. https://doi.org/10.3390/en10010089

Gasser T, Guivarch C, Tachiiri K et al (2015) Negative emissions physically needed to keep global warming below $2{ }^{\circ} \mathrm{C}$. Nat Commun 6:ncomms8958. https://doi.org/10.1038/ncomms8958

Geden O (2015) Policy: climate advisers must maintain integrity. Nature 521:27-28. https://doi.org/10.1038 $1521027 \mathrm{a}$

Geden O, Löschel A (2017) Define limits for temperature overshoot targets. Nat Geosci 10:881-882. https://doi. org/10.1038/s41561-017-0026-Z

Gernaat DEHJ, Calvin K, Lucas PL et al (2015) Understanding the contribution of non-carbon dioxide gases in deep mitigation scenarios. Glob Environ Chang 33:142-153. https://doi.org/10.1016/j. gloenvcha.2015.04.010

Grieneisen ML, Zhang M (2011) The current status of climate change research. Nat Clim Chang 1:nclimate1093. https://doi.org/10.1038/nclimate1093

Griffin B, Buisson P, Criqui P, Mima S (2014) White Knights: will wind and solar come to the rescue of a looming capacity gap from nuclear phase-out or slow CCS start-up? Clim Chang 123:623-635. https://doi. org/10.1007/s10584-013-0963-5

Grubler A, Wilson C, Bento N et al (2018) A low energy demand scenario for meeting the $1.5^{\circ} \mathrm{C}$ target and sustainable development goals without negative emission technologies. Nat Energy 3:515-527. https:/doi. org/10.1038/s41560-018-0172-6

Guest G, MacQueen KM, Namey EE (2012) Applied thematic analysis. SAGE Publishing

Haddaway NR, Macura B (2018) The role of reporting standards in producing robust literature reviews. Nat Clim Chang 8(6):444. https://doi.org/10.1038/s41558-018-0180-3

Haunschild R, Bornmann L, Marx W (2016) Climate change research in view of bibliometrics. PLoS One 11: e0160393. https://doi.org/10.1371/journal.pone.0160393

Heck V, Gerten D, Lucht W, Popp A (2018) Biomass-based negative emissions difficult to reconcile with planetary boundaries. Nat Clim Chang 8:151-155. https://doi.org/10.1038/s41558-017-0064-y

Hendriks C, Graus W, van Bergen F (2004) Global carbon dioxide storage potential and costs. Technical Report Ecofys

Hirth L, Steckel JC (2016) The role of capital costs in decarbonizing the electricity sector. Environ Res Lett 11: 114010. https://doi.org/10.1088/1748-9326/11/11/114010

Hoegh-Guldberg, O, Jacob D, Taylor M et al (2018) Impacts of $1.5^{\circ} \mathrm{C}$ global warming on natural and human system. In: Global warming of $1.5^{\circ} \mathrm{C}$. An IPCC Special Report on the impacts of global warming of $1.5^{\circ} \mathrm{C}$ above pre-industrial levels and related global greenhouse gas emission pathways, in the context of strengthening the global response to the threat of climate change, sustainable development, and efforts to eradicate poverty [Masson-Delmotte, V., P. Zhai, H.-O. Pörtner, D. Roberts, J. Skea, P.R. Shukla, A. Pirani, W. Moufouma-Okia, C. Péan, R. Pidcock, S. Connors, J.B.R. Matthews, Y. Chen, X. Zhou, M.I. Gomis, E. Lonnoy, T. Maycock, M. Tignor, and T. Waterfield (eds.)]. In Press

Holz C, Siegel LS, Johnston E et al (2018) Ratcheting ambition to limit warming to $1.5^{\circ} \mathrm{C}$-trade-offs between emission reductions and carbon dioxide removal. Environ Res Lett 13:064028. https://doi.org/10.1088/17489326/aac0c1

Humpenöder F, Popp A, Dietrich JP et al (2014) Investigating afforestation and bioenergy CCS as climate change mitigation strategies. Environ Res Lett 9:064029-064029. https://doi.org/10.1088/1748-9326/9/6/064029

Huppmann D, Rogelj J, Kriegler E et al (2018) A new scenario resource for integrated $1.5^{\circ} \mathrm{C}$ research. Nat Clim Chang 8:1027-1030. https://doi.org/10.1038/s41558-018-0317-4

IPCC (2014) Summary for policymakers. In: Edenhofer O, Pichs-Madruga R, Sokona Y, et al. (eds) Climate change 2014: mitigation of climate change. Contribution of Working Group III to the Fifth Assessment Report of the Intergovernmental Panel on Climate Change. Cambridge University Press, Cambridge, United Kingdom and New York, NY, USA

IPCC (2018) Summary for policymakers. In: Global warming of $1.5^{\circ} \mathrm{C}$. An IPCC Special Report on the impacts of global warming of $1.5^{\circ} \mathrm{C}$ above pre-industrial levels and related global greenhouse gas emission pathways, in the context of strengthening the global response to the threat of climate change, sustainable 
development, and efforts to eradicate poverty [Masson-Delmotte, V., P. Zhai, H.-O. Pörtner, D. Roberts, J. Skea, P.R. Shukla, A. Pirani, W. Moufouma-Okia, C. Péan, R. Pidcock, S. Connors, J.B.R. Matthews, Y. Chen, X. Zhou, M.I. Gomis, E. Lonnoy, T. Maycock, M. Tignor, and T. Waterfield (eds.)]. World Meteorological Organization, Geneva, Switzerland, 32 pp.

Iyer G, Hultman N, Eom J et al (2015) Diffusion of low-carbon technologies and the feasibility of long-term climate targets. Technol Forecast Soc Chang 90:103-118. https://doi.org/10.1016/j.techfore.2013.08.025

Johnson N, Parker N, Ogden J (2014) How negative can biofuels with CCS take us and at what cost? Refining the economic potential of biofuel production with CCS using spatially-explicit modeling. Energy Procedia 63:6770-6791. https://doi.org/10.1016/j.egypro.2014.11.712

Kanudia A, Labriet M, Loulou R (2014) Effectiveness and efficiency of climate change mitigation in a technologically uncertain world. Clim Chang 123:543-558. https://doi.org/10.1007/s10584-013-0854-9

Keith DW, Ha-Duong M, Stolaroff JK (2006) Climate strategy with CO2 capture from the air. Clim Chang 74: 17-45. https://doi.org/10.1007/s10584-005-9026-X

Keller K, McInerney D, Bradford DF (2008) Carbon dioxide sequestration: how much and when? Clim Chang 88:267-291. https://doi.org/10.1007/s10584-008-9417-x

Keller DP, Lenton A, Scott V et al (2018) The Carbon Dioxide Removal Model Intercomparison Project (CDRMIP): rationale and experimental protocol for CMIP6. Geosci Model Dev 11:1133-1160. https://doi.org/10.5194/gmd-11-1133-2018

Klein D, Bauer N, Bodirsky B et al (2011) Bio-IGCC with CCS as a long-term mitigation option in a coupled energy-system and land-use model. Energy Procedia 4:2933-2940. https://doi.org/10.1016/j. egypro.2011.02.201

Klein D, Luderer G, Kriegler E et al (2014) The value of bioenergy in low stabilization scenarios: an assessment using REMIND-MAgPIE. Clim Chang 123:705-718. https://doi.org/10.1007/s10584-013-0940-z

Kober TT, van der Zwaan B, Rösler HH (2014) Emission certificate trade and costs under regional burdensharing regimes for a $2^{\circ} \mathrm{C}$ climate change control target. Climate Change Economics 05:1440001-1440001. https://doi.org/10.1142/S2010007814400016

Kober T, Panos E, Volkart K (2018) Energy system challenges of deep global CO2 emissions reduction under the world energy council's scenario framework. In: Giannakidis G, Karlsson K, Labriet M, Gallachóir B (eds) Limiting global warming to well below $2{ }^{\circ} \mathrm{C}$ : energy system modelling and policy development. Springer, Cham, pp 17-31

Koelbl BS (2016) Deployment potential and macro-economic impacts of carbon dioxide capture and storage in the future energy system. Ph.D. thesis. ISBN: 9789086720712

Koelbl BS, van den Broek MA, Faaij APC, van Vuuren DP (2014) Uncertainty in carbon capture and storage (CCS) deployment projections: a cross-model comparison exercise. Clim Chang 123:461-476. https://oi. org/10.1007/s10584-013-1050-7

Kowarsch et al. (2016) Scientific assessments to facilitate deliberative policy learning. https://www.nature.com/ articles/palcomms 201692

Kowarsch et al. (2017) A road map for global environmental assessments Nat Clim Chang. https:// www.nature.com/articles/nclimate3307

Kreidenweis U, Humpenoder F, Stevanovic M, et al (2016) Afforestation to mitigate climate change: impacts on food prices under consideration of albedo effects. Environ Res Lett 11:. doi: https://doi.org/10.1088/17489326/11/8/085001

Krey V, Riahi K (2009) Implications of delayed participation and technology failure for the feasibility, costs, and likelihood of staying below temperature targets - greenhouse gas mitigation scenarios for the 21 st century. Energy Econ 31:S94-S106. https://doi.org/10.1016/j.eneco.2009.07.001

Krey V, Luderer G, Clarke L, Kriegler E (2014) Getting from here to there - energy technology transformation pathways in the EMF27 scenarios. Clim Chang 123:369-382. https://doi.org/10.1007/s10584-013-0947-5

Kriegler E, Edenhofer O, Reuster L et al (2013a) Is atmospheric carbon dioxide removal a game changer for climate change mitigation? Clim Chang 118:45-57. https://doi.org/10.1007/s10584-012-0681-4

Kriegler E, Tavoni M, Riahi K, van Vuuren DP (2013b) Introducing the limits special issue. Climate Change Economics 04:1302002-1302002. https://doi.org/10.1142/S2010007813020028

Kriegler E, Weyant JP, Blanford GJ et al (2014) The role of technology for achieving climate policy objectives : overview of the EMF 27 study on global technology and climate policy strategies. Clim Chang. https://doi. org/10.1007/s10584-013-0953-7

Kriegler E, Petermann N, Krey V et al (2015a) Diagnostic indicators for integrated assessment models of climate policy. Technol Forecast Soc Chang 90:45-61. https://doi.org/10.1016/j.techfore.2013.09.020

Kriegler E, Riahi K, Bauer N et al (2015b) Making or breaking climate targets: the AMPERE study on staged accession scenarios for climate policy. Technol Forecast Soc Chang 99:273-276. https://doi.org/10.1016/j. techfore.2015.07.011 
Kriegler E, Riahi K, Bosetti V et al (2015c) Introduction to the AMPERE model intercomparison studies on the economics of climate stabilization. Technol Forecast Soc Chang 90(part a):1-7. https://doi.org/10.1016/j. techfore.2014.10.012

Kriegler E, Mouratiadou I, Luderer G, et al (2016) Will economic growth and fossil fuel scarcity help or hinder climate stabilization? Clim Chang 1-16. doi: https://doi.org/10.1007/s10584-016-1668-3

Kriegler E, Bauer N, Popp A et al (2017) Fossil-fueled development (SSP5): an energy and resource intensive scenario for the 21st century. Glob Environ Chang 42:297-315. https://doi.org/10.1016/j. gloenvcha.2016.05.015

Kriegler E, Bertram C, Kuramochi T et al (2018a) Short term policies to keep the door open for Paris climate goals. Environ Res Lett 13:074022. https://doi.org/10.1088/1748-9326/aac4f1

Kriegler E, Luderer G, Bauer N et al (2018b) Pathways limiting warming to $1.5^{\circ} \mathrm{C}$ : a tale of turning around in no time? Phil Trans R Soc A 376:20160457. https://doi.org/10.1098/rsta.2016.0457

Kunreuther H, Gupta S, Bosetti V, et al (2014) Integrated risk and uncertainty assessment of climate change response policies. In: Edenhofer O, Pichs-Madruga R, Sokona Y, et al. (eds) Climate change 2014: mitigation of climate change. Contribution of Working Group III to the Fifth Assessment Report of the Intergovernmental Panel on Climate Change. Cambridge University Press, Cambridge, United Kingdom and New York, NY, USA

Lackner KS (2016) The promise of negative emissions. Science 354:714-714. https://doi.org/10.1126/science. aal2432

Lamb WF, Creutzig F, Callaghan MW et al (2019) Learning about urban climate solutions from case studies. Nat Clim Chang 9:279-287. https://doi.org/10.1038/s41558-019-0440-x

Lehtilä A, Koljonen T (2018) Pathways to post-fossil economy in a well below $2{ }^{\circ} \mathrm{C}$ world. In: Giannakidis $\mathrm{G}$, Karlsson K, Labriet M, Gallachóir B (eds) Limiting global warming to well below $2{ }^{\circ} \mathrm{C}$ : energy system modelling and policy development. Springer, Cham, pp 33-49

Leibowicz BD, Krey V, Grubler A (2016) Representing spatial technology diffusion in an energy system optimization model. Technol Forecast Soc Chang 103:350-363. https://doi.org/10.1016/j. techfore.2015.06.001

Leimbach M, Bauer N, Baumstark L et al (2010) Technological change and international trade - insights from REMIND-R. Energy J 31:109-136. https://doi.org/10.5547/ISSN0195-6574-EJ-Vol31-NoSI-5

Lemoine DM, Fuss S, Szolgayova J et al (2012) The influence of negative emission technologies and technology policies on the optimal climate mitigation portfolio. Clim Chang 113:141-162. https://doi.org/10.1007 /s10584-011-0269-4

Lewis S (2015) The dirty secret of the Paris climate Deal. Foreign Policy

Lomax G, Lenton TM, Adeosun A, Workman M (2015) Investing in negative emissions. Nat Clim Chang 5:498500. https://doi.org/10.1038/nclimate2627

Luckow P, Wise M, Dooley J, Kim SH (2010) Large-scale utilization of biomass energy and carbon dioxide capture and storage in the transport and electricity sectors under stringent $\mathrm{CO} 2$ concentration limit scenarios ScienceDirect. Int J Greenh Gas Con 4:. doi: https://doi.org/10.1016/j.ijggc.2010.06.002

Luderer G, Pietzcker RC, Bertram C et al (2013) Economic mitigation challenges: how further delay closes the door for achieving climate targets. Environ Res Lett 8:034033. https://doi.org/10.1088/1748-9326/8/3 $/ 034033$

Luderer G, Krey V, Calvin K, et al (2014) The role of renewable energy in climate stabilization: results from the EMF27 scenarios. Climatic Change submitted

Luderer G, Bertram C, Calvin K et al (2016a) Implications of weak near-term climate policies on long-term mitigation pathways. Clim Chang 136:127-140. https://doi.org/10.1007/s10584-013-0899-9

Luderer G, Kriegler E, Delsa L, et al (2016b) Deep decarbonization towards $1.5^{\circ} \mathrm{C}-2{ }^{\circ} \mathrm{C}$ stabilization: policy findings from the ADVANCE project

Luderer G, Vrontisi Z, Bertram C et al (2018) Residual fossil CO 2 emissions in $1.5-2{ }^{\circ} \mathrm{C}$ pathways. Nat Clim Chang 8:626-633. https://doi.org/10.1038/s41558-018-0198-6

Magné B, Kypreos S, Turton H (2010) Technology options for low stabilization pathways with MERGE. Energy J 31:83-108

Makihira A, Barreto L, Riahi K (2003) Assessment of alternative hydrogen pathways: natural gas and biomass. International Institute for Applied Systems Analysis (IIASA)

Manne AS, Richels RG (2006) The role of non-CO2 greenhouse gases and carbon sinks in meeting climate objectives. Energy J SI2006:. doi: https://doi.org/10.5547/ISSN0195-6574-EJ-VolSI2006-NoSI3-20

Manoussi V, Shayegh S, Tavoni M (2017) Optimal carbon dioxide removal in face of ocean carbon sink feedback - FEEM working papers. Fondazione Eni Enrico Mattei, Milano, Italy

Marcucci A, Kypreos S, Panos E (2017) The road to achieving the long-term Paris targets: energy transition and the role of direct air capture. Clim Chang 144:181-193. https://doi.org/10.1007/s10584-017-2051-8 
McCollum D, Krey V, Kolp P et al (2014) Transport electrification: a key element for energy system transformation and climate stabilization. Clim Chang 123:651-664. https://doi.org/10.1007/s10584-013-0969-z

Meinshausen M, Smith SJ, Calvin K et al (2011) The RCP greenhouse gas concentrations and their extensions from 1765 to 2300. Clim Chang 109:213. https://doi.org/10.1007/s10584-011-0156-Z

Méjean A, Guivarch C, Lefèvre J, Hamdi-Cherif M (2018) The transition in energy demand sectors to limit global warming to $1.5^{\circ} \mathrm{C}$. Energ Effic. https://doi.org/10.1007/s12053-018-9682-0

Millar RJ, Fuglestvedt JS, Friedlingstein P, et al (2017) Emission budgets and pathways consistent with limiting warming to $1.5^{\circ} \mathrm{C}$. Nat Geosci ngeo3031. doi: https://doi.org/10.1038/ngeo3031

Ming T, de Richter R, Shen S, Caillol S (2016) Fighting global warming by greenhouse gas removal: destroying atmospheric nitrous oxide thanks to synergies between two breakthrough technologies. Environ Sci Pollut Res 23:6119-6138. https://doi.org/10.1007/s11356-016-6103-9

Mintenig J, Khabbazan MM, Held H (2017) The role of Bioenergy and Carbon Capture and Storage (BECCS) in the case of delayed climate policy - insights from cost-risk analysis. Earth System Dynamics Discussions In review: doi: https://doi.org/10.5194/esd-2017-117

Minx JC, Callaghan M, Lamb WF et al (2017a) Learning about climate change solutions in the IPCC and beyond. Environ Sci Pol 77:252-259. https://doi.org/10.1016/j.envsci.2017.05.014

Minx JC, Lamb WF, Callaghan MW et al (2017b) Fast growing research on negative emissions. Environ Res Lett 12:035007. https://doi.org/10.1088/1748-9326/aa5ee5

Minx JC, Lamb WF, Callaghan MW et al (2018) Negative emissions - part 1: research landscape and synthesis. Environ Res Lett 13:063001. https://doi.org/10.1088/1748-9326/aabf9b

Mori S, Washida T, Kurosawa A, Masui T (2018) Assessment of mitigation strategies as tools for risk management under future uncertainties: a multi-model approach. Sustain Sci 13:329-349. https://oi. org/10.1007/s11625-017-0521-6

Mouratiadou I, Luderer G, Bauer N, Kriegler E (2016) Emissions and their drivers: sensitivity to economic growth and fossil fuel availability across world regions. Clim Chang 136:23-37. https://doi.org/10.1007 /s10584-015-1368-4

Mousavi B, Blesl M, Giannakidis G et al (2018) Analysis of the relative roles of supply-side and demand-side measures in tackling the global $1.5^{\circ} \mathrm{C}$ target. In: Limiting global warming to well below $2{ }^{\circ} \mathrm{C}$ : energy system modelling and policy development. Springer, Cham, pp 67-83

Muratori M, Calvin K, Wise M et al (2016) Global economic consequences of deploying bioenergy with carbon capture and storage (BECCS). Environ Res Lett 11:095004-095004. https://doi.org/10.1088/1748-9326/11 /9/095004

Nakagawa S, Samarasinghe G, Haddaway N et al (2018) Research weaving: visualizing the future of research synthesis. Trends Ecol Evol 34:224-238. https://doi.org/10.1016/j.tree.2018.11.007

Nemet GF, Callaghan MW, Creutzig F et al (2018) Negative emissions_part 3: Innovation and Upscaling. Environ Res Lett 13:063003. https://doi.org/10.1088/1748-9326/aabff4

Obersteiner M, Azar C, Möllersten K, et al (2002) Biomass energy, carbon removal and permanent sequestration - a 'real option' for managing climate risk. International Institute for Applied Systems Analysis (IIASA)

Obersteiner M, Bednar J, Wagner F et al (2018) How to spend a dwindling greenhouse gas budget. Nat Clim Chang 8:7-10. https://doi.org/10.1038/s41558-017-0045-1

Parson EA (2017) Opinion: climate policymakers and assessments must get serious about climate engineering. Proc Natl Acad Sci U S A 114:9227-9230. https://doi.org/10.1073/pnas.1713456114

Peters GP, Geden O (2017) Catalysing a political shift from low to negative carbon. Nat Clim Chang 7:619-621. https://doi.org/10.1038/nclimate3369

Petticrew M, McCartney G (2011) Using systematic reviews to separate scientific from policy debate relevant to climate change. Am J Prev Med 40:576-578. https://doi.org/10.1016/j.amepre.2010.12.022

Popp A, Rose SK, Calvin K et al (2014) Land-use transition for bioenergy and climate stabilization: model comparison of drivers, impacts and interactions with other land use based mitigation options. Clim Chang 123:495-509. https://doi.org/10.1007/s10584-013-0926-x

Popp A, Calvin K, Fujimori S et al (2017) Land-use futures in the shared socio-economic pathways. Glob Environ Chang 42:331-345. https://doi.org/10.1016/j.gloenvcha.2016.10.002

Rao S, Riahi K (2006) The role of non-CO2 greenhouse gases in climate change mitigation: long-term scenarios for the 21 st century. doi: https://doi.org/10.5547/ISSN0195-6574-EJ-VolSI2006-NoSI3-9

Reilly J, Melillo J, Cai Y et al (2012) Using land to mitigate climate change: hitting the target, recognizing the trade-offs. Environ Sci Technol 46:5672-5679. https://doi.org/10.1021/es2034729

Riahi K, Grübler A, Nakicenovic N (2007) Scenarios of long-term socio-economic and environmental development under climate stabilization. Technol Forecast Soc Chang 74:887-935. https://doi.org/10.1016/j. techfore.2006.05.026

Riahi K, Kriegler E, Johnson N et al (2015) Locked into Copenhagen Pledges - implications of short-term emission targets for the cost and feasibility of long-term climate goals. Technol Forecast Soc Chang 
Riahi K, van Vuuren DP, Kriegler E et al (2017) The shared socioeconomic pathways and their energy, land use, and greenhouse gas emissions implications: an overview. Glob Environ Chang 42:153-168. https://oi. org/10.1016/j.gloenvcha.2016.05.009

Ricci O (2012) Providing adequate economic incentives for bioenergies with $\mathrm{CO} 2$ capture and geological storage. Energy Policy 44:362-373. https://doi.org/10.1016/j.enpol.2012.01.066

Rickels W, Reith F, Keller D et al (2018) Integrated assessment of carbon dioxide removal. Earth's Future 6:565582. https://doi.org/10.1002/2017EF000724

Rogelj J, Luderer G, Pietzcker RC et al (2015) Energy system transformations for limiting end-of-century warming to below $1.5^{\circ} \mathrm{C}$. Nat Clim Chang 5:519-527. https://doi.org/10.1038/nclimate2572

Rogelj J, Popp A, Calvin KV et al (2018a) Scenarios towards limiting global mean temperature increase below $1.5^{\circ} \mathrm{C}$. Nat Clim Chang 8:325-332. https://doi.org/10.1038/s41558-018-0091-3

Rogelj J, Shindell K, Jiang S et al (2018b) Mitigation pathways compatible with $1.5^{\circ} \mathrm{C}$ in the context of sustainable development. In: Global warming of $1.5^{\circ} \mathrm{C}$. An IPCC Special Report on the impacts of global warming of $1.5^{\circ} \mathrm{C}$ above pre-industrial levels and related global greenhouse gas emission pathways, in the context of strengthening the global response to the threat of climate change, sustainable development, and efforts to eradicate poverty [Masson-Delmotte, V., P. Zhai, H.-O. Pörtner, D. Roberts, J. Skea, P.R. Shukla, A. Pirani, W. Moufouma-Okia, C. Péan, R. Pidcock, S. Connors, J.B.R. Matthews, Y. Chen, X. Zhou, M.I. Gomis, E. Lonnoy, T. Maycock, M. Tignor, and T. Waterfield (eds.)]. In Press

Rose SK, Kriegler E, Bibas R et al (2014a) Bioenergy in energy transformation and climate management. Clim Chang 123:477-493. https://doi.org/10.1007/s10584-013-0965-3

Rose SK, Richels R, Smith S et al (2014b) Non-Kyoto radiative forcing in long-run greenhouse gas emissions and climate change scenarios. Clim Chang 123:511-525. https://oi.org/10.1007/s10584-013-0955-5

Roy J, Tschakert P, Waisman H et al (2018) Sustainable development, poverty eradication and reducing inequalities. In: Global warming of $1.5^{\circ} \mathrm{C}$. An IPCC Special Report on the impacts of global warming of $1.5^{\circ} \mathrm{C}$ above pre-industrial levels and related global greenhouse gas emission pathways, in the context of strengthening the global response to the threat of climate change, sustainable development, and efforts to eradicate poverty [Masson-Delmotte, V., P. Zhai, H.-O. Pörtner, D. Roberts, J. Skea, P.R. Shukla, A. Pirani, W. Moufouma-Okia, C. Péan, R. Pidcock, S. Connors, J.B.R. Matthews, Y. Chen, X. Zhou, M.I. Gomis, E. Lonnoy, T. Maycock, M. Tignor, and T. Waterfield (eds.)]. In Press

Sanchez DL, Nelson JH, Johnston J et al (2015) Biomass enables the transition to a carbon-negative power system across western North America. Nat Clim Chang 5:230-234. https://doi.org/10.1038/nclimate2488

Sanchez DL, Johnson N, McCoy ST, et al (2018) Near-term deployment of carbon capture and sequestration from biorefineries in the United States PNAS 201719695. doi: https://doi.org/10.1073/pnas.1719695115

Sands RD, Förster H, Jones CA, Schumacher K (2014) Bio-electricity and land use in the future agricultural resources model (FARM). Clim Chang 123:719-730. https://doi.org/10.1007/s10584-013-0943-9

Schaeffer M, Gohar L, Kriegler E et al (2015) Mid- and long-term climate projections for fragmented and delayed-action scenarios. Technological forecasting and social change 90(part a):257-268. https://doi. org/10.1016/j.techfore.2013.09.013

Schlamadinger B, Grubb M, Azar C, et al (2001) Carbon sinks and biomass energy production: a study of linkages, options and implications 84

Scott V, Geden O (2018) The challenge of carbon dioxide removal for EU policy-making. Nat Energy 3:350352. https://doi.org/10.1038/s41560-018-0124-1

Séférian R, Rocher M, Guivarch C, Colin J (2018) Constraints on biomass energy deployment in mitigation pathways: the case of water scarcity. Environ Res Lett 13:054011. https://doi.org/10.1088/1748-9326/aabcd7

Selosse S, Ricci O (2014) Achieving negative emissions with BECCS (bioenergy with carbon capture and storage) in the power sector: new insights from the TIAM-FR (TIMES Integrated Assessment Model France) model. Energy 76:967-975. https://doi.org/10.1016/j.energy.2014.09.014

Selosse S, Ricci O (2017) Carbon capture and storage: lessons from a storage potential and localization analysis. Appl Energy 188:32-44. https://doi.org/10.1016/j.apenergy.2016.11.117

Smith P, Bustamante M, Ahammad H, et al (2014) Agriculture, forestry and other land use (AFOLU). In: Edenhofer O, Pichs-Madruga R, Sokona Y, et al. (eds) Climate change 2014: mitigation of climate change. Contribution of Working Group III to the Fifth Assessment Report of the Intergovernmental Panel on Climate Change. Cambridge University Press, Cambridge, United Kingdom and New York, NY, USA

Sohngen B, Sedjo R (2006) Carbon sequestration in global forests under different carbon price regimes. Energy J 27:109-126

Stavins, Zou J, Brewer T, et al (2014) International cooperation: agreements and instruments. In: Edenhofer O, Pichs-Madruga R, Sokona Y, et al. (eds) Climate change 2014: mitigation of climate change. Contribution of Working Group III to the Fifth Assessment Report of the Intergovernmental Panel on Climate Change. Cambridge University Press, Cambridge, United Kingdom and New York, NY, USA 
Stolaroff JK, Bhattacharyya S, Smith CA et al (2012) Review of methane mitigation technologies with application to rapid release of methane from the Arctic. Environ Sci Technol 46:6455-6469. https://doi. org/10.1021/es204686w

Strefler J, Bauer N, Amann T, et al (2015) Enhanced weathering and BECCS - are carbon dioxide removal technologies complements or substitutes? Abu Dhabi, p 10

Strefler J, Bauer N, Kriegler E et al (2018) Between Scylla and Charybdis: delayed mitigation narrows the passage between large-scale CDR and high costs. Environ Res Lett 13:044015. https://doi.org/10.1088 /1748-9326/aab2ba

Strengers BJ, Minnen JGV, Eickhout B (2008) The role of carbon plantations in mitigating climate change: potentials and costs. Clim Chang 88:343-366. https://doi.org/10.1007/s10584-007-9334-4

Su X, Takahashi K, Fujimori S et al (2017) Emission pathways to achieve $2.0^{\circ} \mathrm{C}$ and $1.5^{\circ} \mathrm{C}$ climate targets. Earth's Future 5:592-604. https://doi.org/10.1002/2016EF000492

Su X, Shiogama H, Tanaka K et al (2018) How do climate-related uncertainties influence 2 and $1.5^{\circ} \mathrm{C}$ pathways? Sustain Sci 13:291-299. https://doi.org/10.1007/s11625-017-0525-2

Tanaka K, O’Neill BC (2018) The Paris Agreement zero-emissions goal is not always consistent with the $1.5^{\circ} \mathrm{C}$ and $2{ }^{\circ} \mathrm{C}$ temperature targets. Nat Clim Chang 8:319-324. https://doi.org/10.1038/s41558-018-0097-X

Tavoni M, Socolow R (2013) Modeling meets science and technology: an introduction to a special issue on negative emissions. Climate Change Economics 118:1-14. https://doi.org/10.1007/s10584-013-0757-9

Tavoni M, Sohngen B, Bosetti V (2007) Forestry and the carbon market response to stabilize climate 35:53465353. doi: https://doi.org/10.1016/j.enpol.2006.01.036

Tavoni M, Kriegler E, Aboumahboub T et al (2013) The distribution of the major economies' effort in the Durban platform scenarios. Climate Change Economics 04:1340009-1340009. https://doi.org/10.1142 /S2010007813400095

Tavoni M, Bosetti V, Shayegh S et al (2017) Challenges and opportunities for integrated modeling of climate engineering. Social Science Research Network, Rochester

Tokarska KB, Gillett NP (2018) Cumulative carbon emissions budgets consistent with $1.5^{\circ} \mathrm{C}$ global warming. Nat Clim Chang 8:296-299. https://doi.org/10.1038/s41558-018-0118-9

van der Zwaan B, Rösler H, Kober T et al (2013) A cross-model comparison of global long-term technology diffusion under a $2^{\circ} \mathrm{C}$ climate change control target. Climate Change Economics 04:1340013-1340013. https://doi.org/10.1142/S2010007813400137

van Sluisveld MAE, Gernaat DEHJ, Ahina S et al (2013) A multi-model analysis of post-2020 mitigation efforts of five major economies. Climate Change Economics 04:1340012-1340012. https://doi.org/10.1142 /S2010007813400125

van Vliet J, den Elzen MGJ, van Vuuren DP (2009) Meeting radiative forcing targets under delayed participation. Energy Econ 31:S152-S162. https://doi.org/10.1016/j.eneco.2009.06.010

van Vliet J, Hof AF, Mendoza Beltran A et al (2014) The impact of technology availability on the timing and costs of emission reductions for achieving long-term climate targets. Clim Chang 123:559-569. https://doi. org/10.1007/s10584-013-0961-7

van Vuuren DP, Eickhout B, Lucas PL, den Elzen MGJ (2006) Long-term multi-gas scenarios to stabilise radiative forcing - exploring costs and benefits within an integrated assessment framework. Energy $\mathrm{J} 27$ : 201-233

van Vuuren DP, den Elzen MGJ, Lucas PL et al (2007) Stabilizing greenhouse gas concentrations at low levels: an assessment of reduction strategies and costs. Clim Chang 81:119-159. https://doi.org/10.1007/s10584006-9172-9

van Vuuren DP, Deetman S, van Vliet J et al (2013) The role of negative CO2 emissions for reaching $2{ }^{\circ} \mathrm{C}-$ insights from integrated assessment modelling. Clim Chang 118:15-27. https://doi.org/10.1007/s10584-0120680-5

van Vuuren DP, Hof AF, van Sluisveld MAE, Riahi K (2017) Open discussion of negative emissions is urgently needed. Nat Energy 2:902-904. https://doi.org/10.1038/s41560-017-0055-2

van Vuuren DP, Stehfest E, Gernaat DEHJ et al (2018) Alternative pathways to the $1.5{ }^{\circ} \mathrm{C}$ target reduce the need for negative emission technologies. Nat Clim Chang 8:391-397. https://doi.org/10.1038/s41558-018-0119-8

Vaughan NE, Gough C (2016) Expert assessment concludes negative emissions scenarios may not deliver. Environ Res Lett 11:095003. https://doi.org/10.1088/1748-9326/11/9/095003

Vaughan NE, Gough C, Mander S et al (2018) Evaluating the use of biomass energy with carbon capture and storage in low emission scenarios. Environ Res Lett 13:044014. https://doi.org/10.1088/1748-9326/aaaa02

Westgate M, Haddaway N, Cheng SH et al (2018) Software support for environmental evidence synthesis. Nat Ecol Evol 2:588-590. https://doi.org/10.1038/s41559-018-0502-X

Williamson P (2016) Emissions reduction: scrutinize CO2 removal methods. Nature News 530:153. https://doi. org/10.1038/530153a 
Winning M, Pye S, Glynn J et al (2018) How low can we go? The implications of delayed ratcheting and negative emissions technologies on achieving well below $2{ }^{\circ} \mathrm{C}$. In: Limiting global warming to well below 2 ${ }^{\circ} \mathrm{C}$ : energy system modelling and policy development. Springer, Cham, pp 51-65

Wise M, Calvin K, Thomson A et al (2009) Implications of limiting CO2 concentrations for land use and energy. Science 324:1183-1186. https://doi.org/10.1126/science.1168475

Yamagata Y, Hanasaki N, Ito A et al (2018) Estimating water-food-ecosystem trade-offs for the global negative emission scenario (IPCC-RCP2.6). Sustain Sci 13:301-313. https://doi.org/10.1007/s11625-017-0522-5

Yamamoto H, Sugiyama M, Tsutsui J (2014) Role of end-use technologies in long-term GHG reduction scenarios developed with the BET model. Clim Chang 123:583-596. https://doi.org/10.1007/s10584-013-0938-6

Publisher's note Springer Nature remains neutral with regard to jurisdictional claims in published maps and institutional affiliations.

\section{Affiliations}

\section{Jérôme Hilaire ${ }^{1,2} \cdot$ Jan C. Minx ${ }^{1,3} \cdot$ Max W. Callaghan ${ }^{1} \cdot$ Jae Edmonds $^{4} \cdot$ Gunnar Luderer $^{2} \cdot$ Gregory F. Nemet ${ }^{5} \cdot$ Joeri Rogelj $^{6,7,8} \cdot$ Maria del Mar Zamora $^{1}$}

Jan C. Minx

minx@mcc-berlin.net

1 Mercator Research Institute on Global Commons and Climate Change, Torgauer Straße 12-15, EUREF Campus \#19, 10829 Berlin, Germany

2 Member of the Leibniz Association, Postdam Institute for Climate Impact Research (PIK), Potsdam, Germany

3 School of Earth and Environment, University of Leeds, Leeds LS2 9JT, UK

4 Pacific Northwest National Laboratory - Joint Global Change Research Institute, 5825 University Research Court, College Park, MD 20740, USA

5 La Follette School of Public Affairs, University of Wisconsin-Madison, 1225 Observatory Drive, Madison, WI 53706, USA

6 ENE Program, International Institute for Applied Systems Analysis (IIASA), Laxenburg, Austria

7 Grantham Institute for Climate Change and the Environment, Imperial College London, London SW7 2AZ, UK

8 Institute for Atmospheric and Climate Science, ETH Zurich, Zurich, Switzerland 